June 2000

\title{
A comparative study of alternative econometric packages: an application to Italian deposit interests rates
}

\author{
by Giuseppe Bruno and Riccardo De Bonis ${ }^{1}$
}

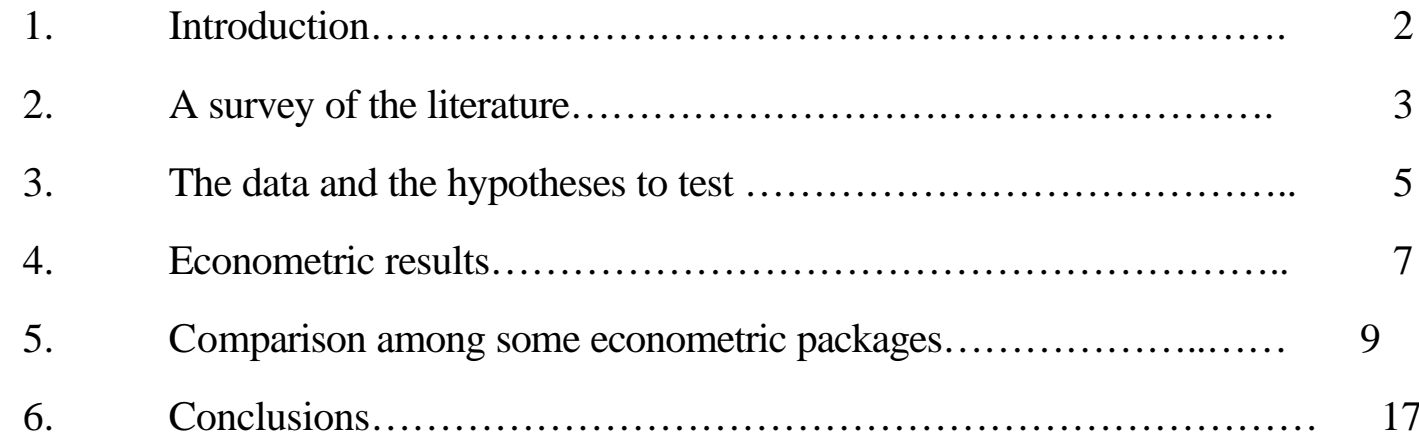

Appendix 1. Program listings.

Appendix 2. The data.

\footnotetext{
${ }^{1}$ Banca d'Italia, Research Department. We thank Filippo Altissimo, Carlo Bianchi, Grazia Marchese and Federico Signorini for helpful comments. Remaining errors are our own. Edoardo Tagliaferri provided research assistance. The views expressed in the paper are those of the authors and do not involve the responsibility of Banca d'Italia.
} 


\section{Introduction}

In recent years, the analysis of banking services' prices in Italy has focused on loan interest rates rather than deposit rates. This may be explained with the attention for the restrictive effects of monetary policy and by the differences on variations in loan prices across Italian regions, particularly between the South and the Center - North. ${ }^{2}$

In this paper we focus on bank deposit rates because they are still one of the main ways in which Italian households invest their financial wealth. We consider the rates charged by banks in the provinces. The empirical analysis is based on a large panel data set (more than 10,000 observations) for the years 1990-99.

Examining the determinants of deposit interest rates, this paper compares alternative econometric packages for the estimation of the panel data. With our abundance of observations, many different specifications have been estimated using the fixed-effects and the random-effects models. The purpose of this work is to respond to the caveats about numerical accuracy raised by McCullogh and Vinod in the June 1999 issue of the Journal of Economic Literature. The authors were very concerned about the scarce attention paid to numerical accuracy in the selection of econometric packages. This choice might drive the market by placing CPU (Central Processing Unit) performance before precision. Considering this treacherous trade-off, we decided to compare the numerical values of the estimates of some popular econometric software.

The paper is divided into six sections. Section two surveys the literature on factors influencing interest rates on deposits, with particular reference to the USA, where the largest number of studies has been conducted. Section three presents the data used in the regressions and the hypotheses we tested. Section four discusses some econometric results of the determinants of interest rates on total deposits, current accounts, savings accounts and certificates of deposit. Section five compares the numerical value of the estimates of three of the most popular econometric packages featuring built-in panel data estimation algorithms: LIMDEP, STATA and TSP. As a numerical benchmark we used Modeleasy Plus, a generalpurpose language containing matrix operations. Finally, Section six states the main conclusions. Appendix 1 documents some program listings we built. Appendix 2 describes the data used in the regressions. 


\section{A survey of the literature}

In the USA the debate on bank interest rates is characterized by two points of view. According to the first view, market concentration is an important factor influencing banks' interest rates. According to the second view, the link between traditional measures of competition and banking prices disappeared with the deregulation of the banking system.

The first view developed from the Supreme Court decision, in the 1963 case Philadelphia National Bank, to consider banking markets "local" rather than national, a decision which highly influenced subsequent interpretations by the antitrust authorities. The idea that banking rates are influenced by market concentration has been confirmed by the structure-conduct-performance paradigm - see Gilbert (1984) and Weiss (1989) for surveys on the subject - and lastly in many papers by Berger and Hannan. They focus their analysis on the retail deposit market. Berger and Hannan (1989a, 1989b and 1991) find a negative relationship between concentration and deposit rates. The results are similar if the Herfindahl index or concentration ratios are used to measure market power. ${ }^{3}$ Sharpe (1997) also finds that concentration impacts negatively on deposit rates.

To evaluate the effect of recent bank mergers in the USA, Prager and Hannan (1998) compare the prices charged by banks involved in mergers to those that are not. The result is that the deposit rates of merged banks decline more than those of other banks because of their greater market power. Neumark and Sharpe (1992) estimate a dynamic model to study the role of concentration in influencing changes in deposit rates following money market rate variations; they find that banks in concentrated markets reduce deposit rates faster and increase them slower because of their market power. In the USA particular attention is given to the California banking market, where deposit rates are usually lower than in other states (the so-called California rate mystery). ${ }^{4}$ Neuberger and Zimmerman (1990), checking for the effect of other variables (growth rate of deposits, branch number, average wage of bank employees) find that higher concentration is one of the factors leading to lower deposit rates in California.

\footnotetext{
${ }^{2}$ See, inter alia, Angeloni, Buttiglione, Ferri and Gaiotti (1995), D’Auria and Foglia (1997), De Bonis and Ferrando (1997).

${ }^{3}$ Hannan (1997) discusses the pros and cons of the Herfindahl index.

${ }^{4}$ See Freixas and Rochet (1998).
} 
The second viewpoint is that the relationship between concentration and deposit rates is not negative. Jackson (1992) has criticized the Berger and Hannan results, arguing that the relation between concentration and deposit rates is not linear, but $U$-shaped. At first, deposit rates decrease as concentration increases. But at a certain point greater concentration implies higher rates, because of the intense competition in markets dominated by a few banks. ${ }^{5}$ However, oligopolistic behavior is constrained by the possibility of new entrants to the markets, according to the mechanism described by the contestable market theory.

This approach leads us to consider the effect on the market of potential competition from new entrants, rather than focusing on the relationship among the incumbents. ${ }^{6}$ This position results from skepticism towards the structure-conduct-performance paradigm, which has been criticized on different grounds. One criticism is that concentration cannot be considered exogenous because it is influenced by the prices charged by firms: in the case of deposits, for example, higher interest rates should lead to gains in market share.

Critics of the relationship between concentration and deposits' compensation add that banking deregulation and the wave of mergers have caused the notion of local markets to blur (see Osborne, 1992). The view that geographic markets are local was formed in the 1960's when unit banking - banks consisting of a single office - was common and branching was heavily restricted in many US states (Radecki, 1998). Now it seems that concentration at the local level - usually measured by the metropolitan statistical areas (MSA) - is no longer relevant to interest rates paid on retail deposits. According to Radecki, the uniformity of bank deposit and loan rates across an entire state suggests that state boundaries now approximate the shape and extent of retail markets better than the MSA. In contrast, concentration at the state level affects deposit rates. The increase in bank size, the development of banking holding companies and the trend towards interstate banking explain why markets are growing larger in geographical scope. Moore (1998) also claims that banking market borders are wider today than in the past.

In Italy the debate is similar. Within the earlier framework characterized by entry barriers to local markets, due to limits in branch openings and mergers, Biscaini, Carosio and Padoa Schioppa (1972) were the first to find that deposit rates were more upwardly rigid than money market rates. These results were in

\footnotetext{
${ }^{5}$ In response, Berger and Hannan (1992) confirm the robustness of their estimates but recognize that the relationship between concentration and rates is time-variant.

${ }^{6}$ Allen, Saunders and Udell (1991) do not find a statistically significant influence of concentration on banking fees.
} 
accordance with the Monti-Klein model, in which the bank is price-maker in the deposit and loan markets. Conigliani and Lanciotti (1979) found a negative correlation between concentration and deposit rates.

More recently, in the new situation of liberalized banking markets, Italian studies have pursued some subjects which recall the American literature. Pittaluga (1994) criticized the structure-conduct-performance approach, because in Italy non-price competition became more important in recent years. More precisely, urban banks applied price competition in the deposit market; while rural banks mostly used forms of nonprice competition, such as enlarging their branch network. Corbisiero and Pesaresi (1999) studied competition in the provinces in which large mergers had been concluded. These merges caused an initial increase in concentration followed by a subsequent decrease. This result stems from the redistribution of market shares from the merged banks to new entrants which adopt more aggressive strategies. The merged bank increases its market share only if it applies higher rates on deposits. This paper, like others in USA, emphasizes the role of the new competitors in influencing the incumbents' behavior.

Looking at macro data, deposit rates seem more upwardly rigid than money market rates in Italy as well. Figure 1 shows that in the years 1995-98 rates on current accounts and certificates of deposit with a maturity of six months slowly followed the increases in six-month Treasury bill rates; on the contrary, deposit rates were quick to follow reductions in Treasury bills' yields (the only exception concerns some months in 1995). This phenomenon is stronger for current accounts, while CD rates appear more reactive to market conditions ${ }^{7}$.

In this paper, however, attention is focused on micro data, whose analysis appears to be of interest even on the basis of the few Italian studies on the same subject.

\section{The data and the hypotheses to test}

The data on interest rates have been taken from the Central Credit Register. A sample of banks produce quarterly data on deposit and loan interest rates. Deposit rates consider deposits of residents in lire greater than 20 million lire (about 10,000 €).

In this paper, the data refer to the 95 Italian provinces and consider around 45 banks. $^{8}$ The dependent variables in the regressions are the interest rates on current accounts, savings accounts,

\footnotetext{
${ }^{7}$ On bank deposits in Italy see Cesarini, Conti, Di Battista (1994) and Di Battista (1996).

${ }^{8}$ The sample contains 41 banks in 1990, 46 in 1991, 47 in 1992, 47 in 1993, 47 in 1994, 47 in 1995, 46 in 1996, 45 in 1997, 44 in 1998, 43 in 1999. Mergers are mainly responsible for these annual changes.
} 
certificates of deposits, total deposits. The certificates of deposit rate, the only one with an agreed maturity among those studied, is generally the highest; the savings accounts normally have the lowest rates. All the rates were raised during the summer of 1992 and the first half of 1995, because of the restrictive monetary policy adopted in those years to counter the foreign exchange crises that occurred.

The analysis considers the years 1990-99; some additional regressions focus on the period 1990-96. Between 1990 and 1996, current accounts were equal on average to 50 per cent of total deposits (Table 1); deposits redeemable at notice decreased from 24 to 12 per cent; certificates of deposit increased from 24 to 35 per cent. In contrast, the years 1997-99 saw a strong increase in the share of current accounts and a contraction in that of certificates of deposit, after the changes in the fiscal treatment of CDs in June 1996. ${ }^{9}$ At the end of 1999 , current accounts rose to 76 per cent of total deposits, while CDs fell to 12 per cent.

Independent and dependent variables are computed with reference to the Italian provinces. The discussion on the definition of the relevant banking market is cumbersome. The choice of the province is motivated by the large availability of data for this geographic area; it is more difficult to collect data on banks on a municipal basis. Moreover, the province is considered the relevant market in deposits for antitrust banking activity in Italy.

The first variable that we use to measure concentration is the Herfindahl index for deposits. Another variable we use is the concentration ratio for the first three banks in the province (R3, the sum of their market shares). The concentration of banking markets decreased considerably in the nineties. As other indicators of competition and diffusion of financial services we use the number of banks and branches in each province. ${ }^{10}$

Different control variables are used in the literature to check for the effect of concentration on interest rates. In this paper we use per capita income in the provinces, which is an indicator of the degree of economic development ${ }^{11}$ and the growth rate of deposits in each province, which may influence the return offered on deposits. ${ }^{12}$

\footnotetext{
${ }^{9}$ See Banca d'Italia, (1996).

${ }^{10}$ Neuberger and Zimmerman (1990), for example, use as regressors the number of banks, together with the concentration ratio $\mathrm{R} 3$.

${ }^{11}$ Radecki (1998), Berger and Hannan (1989a and 1989b) and (1991), Moore (1998) use the per capita GDP as variable influencing deposits' interest rates.

${ }^{12}$ Neuberger and Zimmerman (1990), Radecki (1998), Moore (1998) utilize this variable as regressor.
} 
Other control variables consider banks' costs, which may influence deposit rates. The simple idea is that banks consider the whole structure of costs when they fix deposit rates. In this paper we consider two aggregates: the ratio between costs and total assets and the average staff costs per employee. ${ }^{13}$

Descriptive statistics are reported in Table 2, together with the correlation coefficients of the independent variables. As expected we get a negative correlation between the concentration indicators and the number of banks and branches in the provinces. ${ }^{14}$

\section{Econometric results}

Table 3 reports the estimates for the dependent variable of the interest rate on total deposits. We consider the years 1990-99. The regressions contain yearly dummy variables to control the effects on deposit rates of changes in the monetary policy stance and the business cycle. Dummies are significant, indicating the importance of the evolution of rates over time.

The Herfindahl index does not have a statistically significant influence on deposit rates. A negative effect is produced, however, by the concentration ratio R3. It seems that only the market shares of the most important banks in each province are relevant for the level of interest rates.

Average staff costs per employee (COSPER) have a negative effect on the remuneration of deposits: the higher the value of this variable, the lower the deposit rate. ${ }^{15}$ The negative sign of COSPER (Table 3 ) is also found in a regression in which it is used as the only variable together with HER (Table 4).

The number of banks per province (NBANKS) has a positive effect on deposit rates (Table 3): a larger number of banks may correspond to a higher degree of competition or diffusion of financial services, leading to a higher return for depositors.

13 Neuberger and Zimmerman (1990) find a negative influence of the average wage on deposits' remuneration; Berger e Hannan (1988) find a coefficient with a positive sign. Other variables which could influence the deposits' remuneration are the interbank position and banks' securities issues; we do not deal with these variables now.

${ }^{14}$ Appendix 2 describes the variables used in the regression.

15 This is the same result of Neuberger and Zimmerman (1990)'s paper. The ratio costs/total assets (COSRAT) has a positive coefficient (tab. 3). We offer two interpretations of this result. First, banks with high costs are not able to reduce them in the short period; therefore, they increase their funding to enlarge the scale of operations. Second, inefficient banks (i.e. with higher costs) are subject to a greater failure risk; therefore, they must pay a premium to attract deposits. In a regression where COSRAT is used as regressor with HER, however, the former variable is not statistically significant (table 4). 
The deposit growth rate and provincial per-capita income do not influence deposit rates. It seems that only banking variables exert any influence.

Cross-sections (Table 5) for the period 1990-99 confirm that the Herfindahl index does not influence interest rates for most of the years examined. We also split our sample, considering the five macro-regions (NorthWest, NorthEast, Center, South, Sicily and Sardinia). In this respect Table 6 shows that the Herfindahl index negatively influences deposit rates only in the provinces in the NorthWest and the Center, while the concentration ratio R3 is statistically significant only in the NorthEast and Center. The statistical significance of concentration indicators is accepted only at the 10 per cent level. These regressions also seem to confirm a weak effect of concentration on deposit rates.

Many American studies distinguish the analysis of current account rates from the examination of time or saving deposit rates. This paper also tries to distinguish between the different technical forms of deposits. In the years 1990-96, concentration negatively affects current account rates (Table 7), but not the returns on CDs (Table 8) and deposits redeemable at notice (in the latter case we do not report the results). With reference to certificates of deposit, the result may depend on their fast reaction to variations in money market yields.

We further investigated the determinants of current account rates, running regressions on cross sections for the years 1990-96 (Table 9). The regressions show that the Herfindahl index negatively influences current account deposit rates only in $1990-91 ;^{16}$ in the following years, perhaps as a consequence of the 1990 liberalization of branching in Italy, concentration does not affect deposit rates negatively. ${ }^{17}$ The other control variables maintain their statistical significance.

Coming back to the American debate, it is possible to conclude that the evidence for Italy appears to be nearer to those studies which criticize the Berger and Hannan papers. First, concentration does not influence deposit rates in the period 1990-99. Second, the relationship between concentration and rates seems to vary over time.

In the next section we turn to the analysis of different econometric software for the estimation of panel data.

\footnotetext{
${ }^{16}$ The concentration ratio R3 is statistically significant only in 1990.

${ }^{17}$ On the contrary, the second part of table 9 shows that if the Herfindahl index and the number of banks are used as regressors, the two variables have both a positive and statistically significant coefficient in the years 1993-96. The result corresponds to the efficiency market view, according to which a higher concentration may imply a larger deposits' remuneration, because of the intense competition between the few oligopolists.
} 


\section{Comparison between some econometric packages}

The last two decades have shown a rapid development of software packages featuring complex estimation procedures, without the need for in-depth knowledge of the numerical algorithms and computer science. Most of the econometric and statistical software packages commonly used in academic and business environments have both an interactive and a programmable interface. The main selection criteria for these products are:

1) usability;

2) richness of the commands most frequently required;

3) cost. $^{18}$

To the authors' knowledge there has been only one Panel Data software review in the recent past; this is the paper "Software review" by Pierre Blanchard, in "Econometrics of Panel Data", 1992. The justification for our work is twofold:

a) the impressive pace at which these packages have developed in the last decade;

b) the lack of numerical applications in Blanchard's paper.

Unlike Blanchard, we did not take into account the RATS software package because it does not address the panel data estimation problem in a straightforward way.

Quite often, for a number of different reasons, the numerical accuracy of the answer supplied by the software is overlooked or even neglected. McCullogh and Vinod (1999) gave some examples in which the numerical answers produced by alternative econometric and statistical packages are completely different ${ }^{19}$. Given the importance of this issue, it has become the economist's responsibility to validate the results. The natural question that arises is how to evaluate the numerical accuracy of a complex algorithm. The very simple idea, adopted in this paper, is to compare the results obtained using three different econometric packages available in the research department of the Bank of Italy. The packages compared are:

\footnotetext{
${ }^{18}$ In this paper we do not address this issue.

${ }^{19}$ The authors do not mention the name of the packages used.
} 
1) Time Series Processor (TSP) from TSP Intl. (California);

2) STATA from STATA Corp. (Texas);

3) LIMDEP from Econometrics Ltd. (NY University).

From the usability standpoint, it is important to stress that these packages have been developed in the academic environment to meet special research needs, giving less weight to the user interface, which so far is essentially a simple character interface. These packages are adopted in advanced university lectures and learning to use them represents an important sunk cost for researchers; this gives the usability an idiosyncratic element overriding the weight of objective differences.

As far as the availability of panel estimation commands is concerned, it is possible to verify an overlapping of the three packages examined.

The algorithms required in this paper for the panel estimation, i.e. the fixed and random effects estimators, can be easily interpreted as Generalized Least Squares (GLS) estimates; for this purpose it is sufficient to evaluate the error variance-covariance matrix.

Even though it is possible to perform an interactive estimation, in order to preserve the ability to reproduce the exercises, it has been decided to use programs written in the languages native to the packages. The code relative to these three programs is shown at the end of Appendix 1. A simple visual inspection of the code shows the similarity of the packages considered, as witnessed by the number of lines of code and the output produced. In the use of the STATA package some statistical tests must be explicitly requested.

The main goal of this comparison was to validate the numerical results. As can be checked from the tables shown in Appendix 1, this goal has been fully reached. The numerical value of the estimated coefficients for the fixed and random effects models have been checked by writing the estimation algorithms using the Speakeasy-Modeleasy Plus environment, a package featuring a compact expression for matrix processing. ${ }^{20}$ It is important to mention the fact that the output of STATA also presents a value for the constant. It is, of course, irrelevant for the fixed effects estimator. In fact, after the slope estimation, this constant has been computed with the following formula $\alpha_{\text {within }}=\frac{1}{\sum_{i=1}^{N} T_{i}} \cdot\left(y_{i t}-\beta_{\text {within }} \cdot X_{i t}\right)$.

${ }^{20}$ Modeleasy Plus, EMCC (Palm Harbor, Florida) 
The fixed effect estimator assumes the same numerical value for all three packages. The numerical differences present in the random effects estimation are due to the different criteria adopted for the variance component estimation. Maddala and Mount (1973) offer a comprehensive survey on the estimation methods for the variance component models.

Our analysis focuses on the one-way model in which there is no time-only component in the disturbance term.

Given the following model $y_{i t}=\alpha+X_{i t}^{\prime} \beta+u_{i t} \quad i=1, \ldots, N ; \quad t=1, \ldots, T_{i}$, where the disturbance term can be decomposed in the following way: $u_{i t}=\mu_{i}+v_{i t}$ and $\sigma_{u}^{2}=\sigma_{\mu}^{2}+\sigma_{v}^{2}$, and assuming that the idiosyncratic elements $\mu_{i}$ are random, the estimation of this model consists of the application of the Ordinary Least Squares technique to the following transformed model:

$$
y_{i t}-\theta_{i} \cdot \bar{y}_{i \cdot}=\alpha \cdot\left(1-\theta_{i}\right)+\left(X_{i t}^{\prime}-\theta_{i} \cdot \bar{X}_{i}^{\prime}\right) \cdot \beta+u_{i t}-\theta_{i} \cdot \bar{u}_{i} .
$$

where the bar over the variable represents its temporal average. Let us assume the following:

$\sigma_{v}$ is the standard deviation of the fixed effects estimation (within the regression);

$\sigma_{1}=\sqrt{\sigma_{t o t}^{2}-\sigma_{v}^{2}}$ and $\sigma_{t o t}^{2}$ is the variance of the pooled regression (OLS) achieved with

TSP, if this happens to be negative TSP resorts to the large sample formula given by $\sigma_{1}=\left(S S R_{O L S}-S S R_{\text {Within }}\right) / N O B S$ where $S S R$ stands for residuals sum of squares and $N O B S$ is the total number of observations;

${\tilde{\sigma_{1}}}_{1}^{2}$ is the following standard deviation computed with LIMDEP:

$\tilde{\sigma}_{1}^{2}=\left(\sum_{i}\left(\bar{y}_{i \cdot}-b_{\text {ols }} \cdot \bar{x}_{i \cdot}\right)^{2} /(N f i r m-k-1)\right)-\frac{1}{T_{\text {ave }}} \sigma_{\mathrm{v}}^{2}$ where:

$b_{o l s}$ is the pooled OLS coefficient vector;

Nfirm is the number of different groups;

$k$ is the number of explanatory variables;

depending on certain numerical conditions $b_{\text {ols }}$ can be replaced by $b_{\text {between }}$;

$\hat{\sigma}_{1}$ is the following standard deviation computed with STATA;

$\hat{\sigma}_{1}=\max \left(0, \sqrt{\sigma_{\text {between }}^{2}-\sigma_{v}^{2} / \bar{T}}\right)$, where $\bar{T}$ is the harmonic mean of the set of $T_{i}$.

It is clear that all the numerical differences produced by the random effect estimate are caused by the difference of the small sample formula for the computation of the between-regression variance. The parameter $\theta_{i}$, which discriminates the behaviour of the three packages, is computed in the following ways: 
TSP

$$
\theta_{i}=1-\sqrt{\frac{\sigma_{v}^{2}}{T_{i} \cdot \sigma_{1}^{2}+\sigma_{v}^{2}}}
$$

LIMDEP $\quad \theta_{i}=1-\sqrt{\frac{\sigma_{v}^{2}}{T_{i} \cdot \tilde{\sigma}_{1}^{2}+\sigma_{v}^{2}}}$

STATA

$$
\theta_{i}=1-\sqrt{\frac{\sigma_{v}^{2}}{T_{i} \cdot \hat{\sigma}_{1}^{2}+\sigma_{v}^{2}}}
$$

Although the three estimators are asymptotically equivalent, they show different small-sample properties. $^{21}$

The three software packages have been used to estimate 5 possible model specifications adopting both fixed and random effects. The execution times (on a Risk6000 990 platform) and program sizes are compared in the following table:

\begin{tabular}{|c|c|c|}
\hline Package & $\begin{array}{l}\text { Execution } \\
\text { Time (sec.) }\end{array}$ & of \\
& 5 & 30 \\
\hline TSP & 12 & 28 \\
\hline LIMDEP & 38 & 46 \\
\hline STATA & & \\
\hline
\end{tabular}

On the issue concerning the numerical differences of the random effects estimates, we have analyzed the comparative efficiency of the small-sample properties of the three estimators. This task has been accomplished by running a parametric bootstrap procedure starting from the OLS estimation residuals in one selected specification $^{22}$. The parametric bootstrap used in this exercise is not a bootstrap in the usual sense of the word, it consists in the Monte Carlo exercise described in the following seven steps:

\footnotetext{
${ }^{21}$ On this subject see Swamy and Arora (1972).

${ }^{22}$ See Bellmann, Breitung and Wagner (1989).
} 
1) run a pooled OLS estimation of the coefficients in order to get a numerical value for the residuals;

2) use the OLS residuals to make a biased but consistent estimate of the two variance components $^{23}$

$$
\sigma_{v}^{2}=\frac{1}{N\left(T_{\text {ave }}-1\right)} \sum \sum\left(\hat{\varepsilon}_{i t}-\hat{\varepsilon}_{i .}\right)^{2} \quad \sigma_{\mu}^{2}=\frac{1}{N-1} \sum_{i}\left(\hat{\varepsilon}_{i .}-\hat{\varepsilon}_{. .}\right)^{2}-\frac{\hat{\sigma}_{v}^{2}}{T_{\text {ave }}}
$$

where: $\varepsilon_{. .}=\frac{1}{N \sum_{i} T_{i}} \sum_{i} \sum_{t} \varepsilon_{i t}$ and $\varepsilon_{i .}=\frac{1}{T_{i}} \sum_{t} \varepsilon_{i t}$

3) run a control random effect estimation for computing the true estimated model; this task is carried out separately for each package and provides a true value for the dependent variable and for the structural coefficients;

4) generate two random samples drawn from two normal distributions with zero mean and the standard deviations computed in step 2;

5) add the two simulated residuals to the true value of the dependent variable computed in step 3; in this way it is simulated a new draw for the dependent variable;

6) perform a random effect estimation using this new dataset;

7) compute the average and the standard deviation of the replications.

In what follows the previous seven-step algorithm will be referred to as MCA1 (Monte Carlo A1).

A first interesting result from the application of MCA1 is the CPU time required for the completion of the Monte Carlo experiment. This is shown in the following graph where we compare execution time versus number of replications for the Monte Carlo exercises. TSP is the fastest software.

\footnotetext{
${ }^{23}$ See Wallace and Hussain (1969) for the balanced panel case.
} 


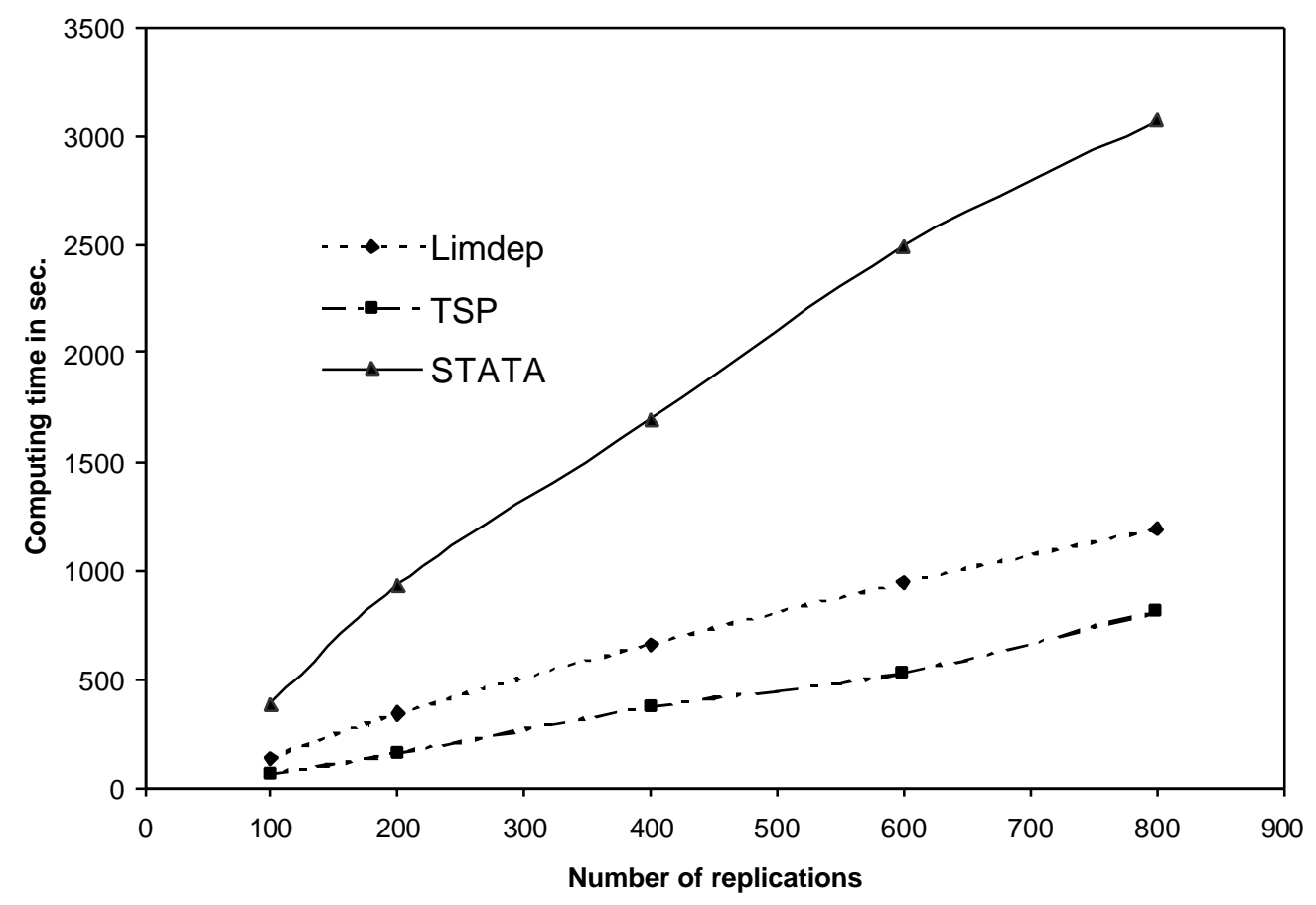

In order to have comparable results, the programs for the Monte Carlo experiments have been written using the looping features made available by each package.

\subsection{Bias and Monte Carlo Variability}

The second and more important insight gained from the application of MCA1 is the evaluation of a bias and a standard deviation for the Monte Carlo replications for each of the packages examined.

The following graphs show the behavior of the bias and the standard deviation around the Monte Carlo mean computed for the coefficients of the Herfindahl concentration index and the normalized cost of personnel: 
Fig. n. 1

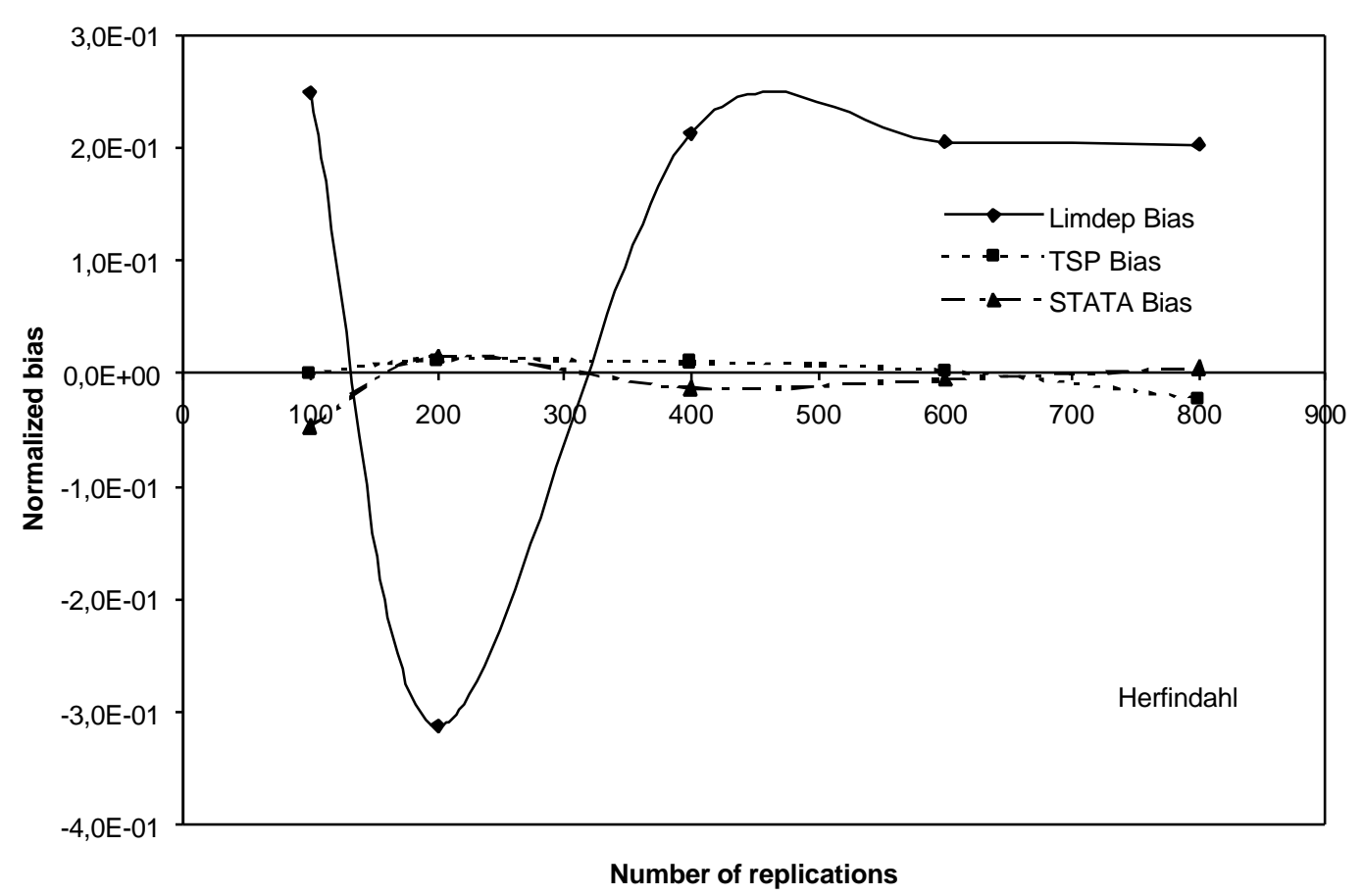

Fig. n. 2

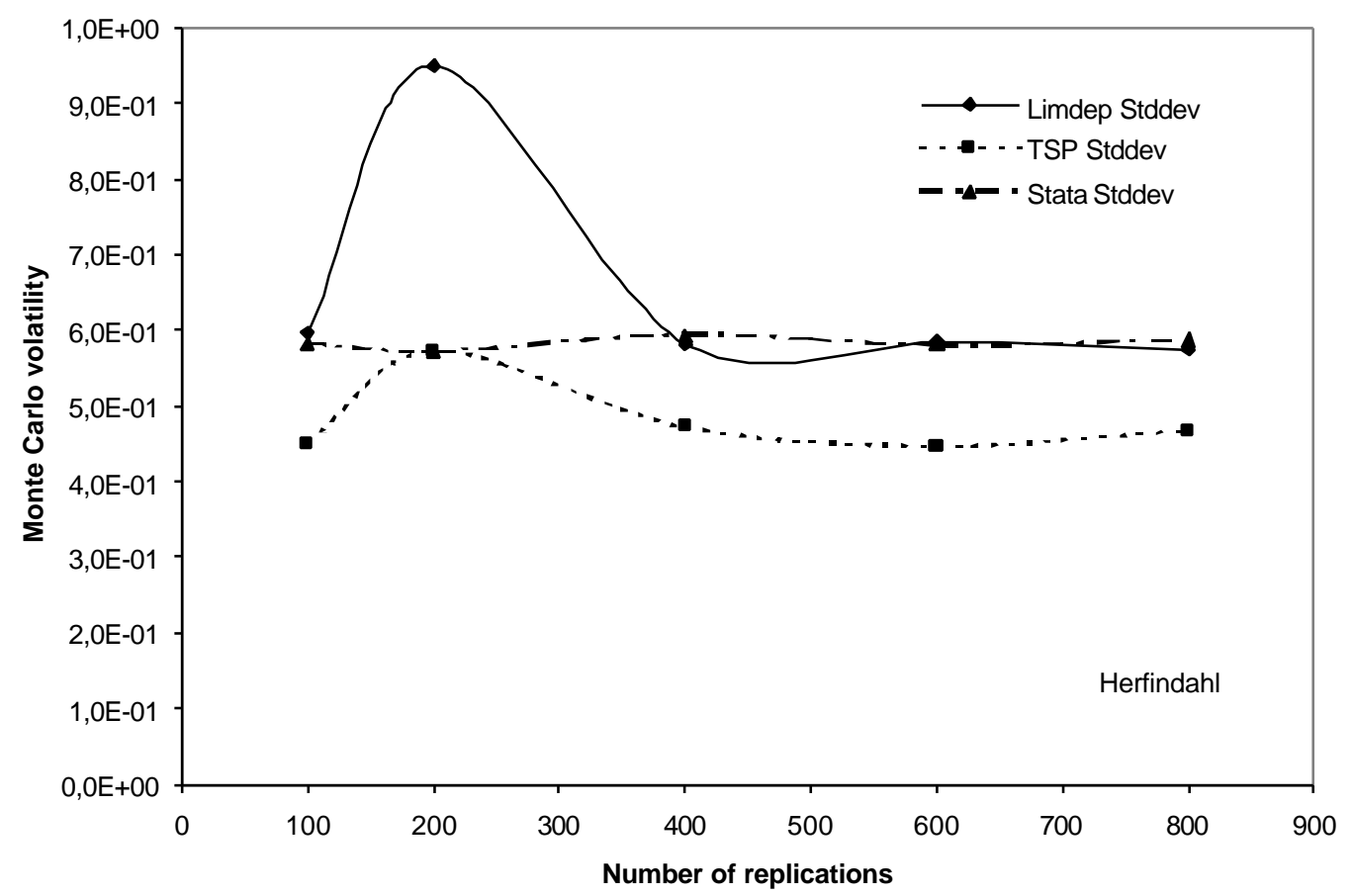


Fig. n. 3

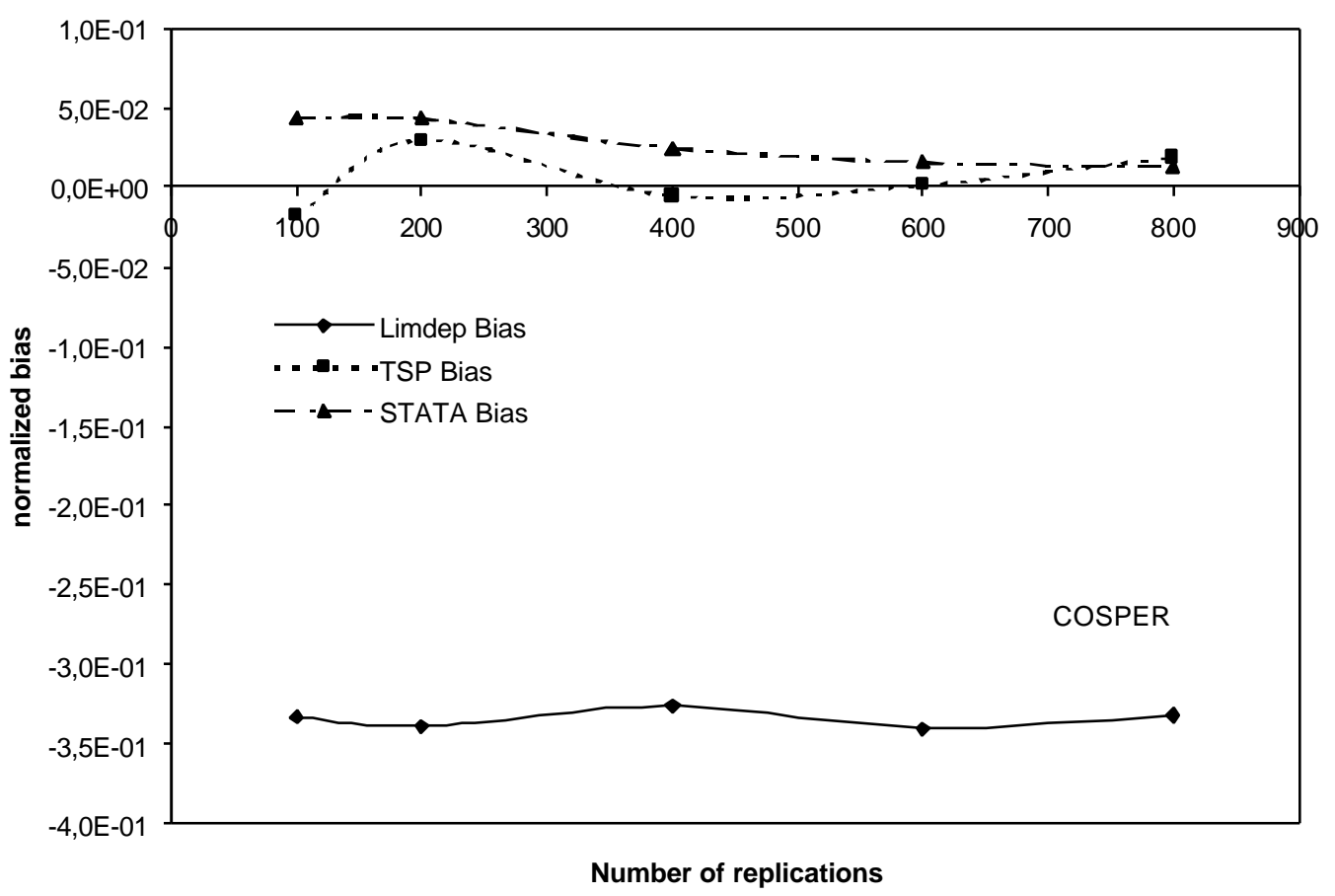

Fig. n. 4

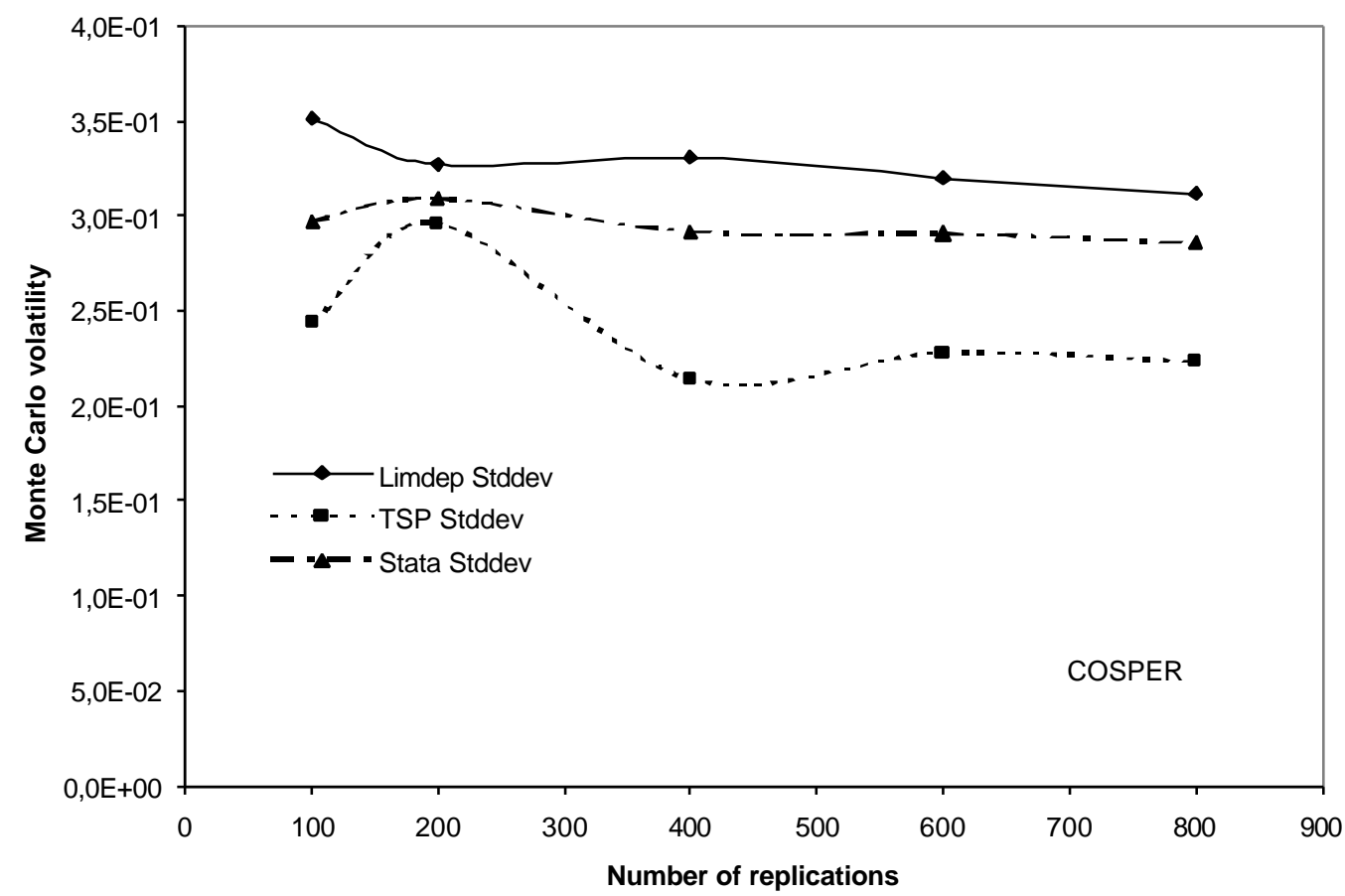

Before drawing any kind of conclusion it is important to note some details of the Monte Carlo experiment: 
1) the data generation process is supplied by using the fitted value of the random effect estimate for each of the three packages;

2) each package has used its own random number generator;

3) the total panel length has been kept fixed.

Taking into account these experimental conditions, observation of the graphs permits some interesting considerations:

- TSP and STATA show about the same behavior for the normalized bias, which appears to approach zero, and the Monte Carlo volatility, which approaches a constant value;

- LIMDEP shows a slightly different behavior: a non zero bias with a variability comparable to the variability generated by TSP and STATA

\section{Conclusions}

This paper compares alternative econometric packages by analyzing the determinants of deposit interest rates in the Italian banking system. The dependent variables are bank interest rates on total deposits, current accounts, and certificates of deposit. We consider the influence on interest rates of the Herfindahl index, the concentration ratio R3, the number of banks in each province, the growth rate of deposits, the ratio between banking costs and total assets, and average staff costs per employee. With this abundance of panel data, many different specifications have been estimated using the fixed-effects and random-effects models. Our purpose was to find an answer to the caveats about numerical accuracy raised by McCullogh and Vinod in the June 1999 issue of the Journal of Economic Literature. They were very concerned about the little attention paid to numerical accuracy in the selection of econometric packages.

The first conclusion of the paper is that the Herfindahl index does not influence deposit interest rates in a panel regression for the years 1990-99; at the same time, the concentration ratio R3 has a negative effect on deposit remuneration. With regard to current accounts, we found a negative effect of concentration in the years 1990-96; cross section regressions show that this result derives mainly from the years 1990-91, when branching was first liberalized. Concentration does not affect interest rates on certificates of deposit and savings deposits. We also found a positive effect of the number of banks per province on deposit rates and a negative effect of average staff costs per employee. Banks seem to take into account their overall structure of costs when deciding the returns to pay on deposits. 
With regard to the numerical comparison of estimators in the three packages examined, fixed-effects algorithms are numerically the same to the available decimal places. Random-effects algorithms yield slightly different results because of the different methods used to compute the between-regression variance. In this respect, we have achieved a more confident outcome than that envisaged by McCullogh and Vinod.

In addition, we compared the relative efficiency of the random-effects algorithms provided by the three packages. This was done by means of a set of suitably designed Monte Carlo experiments, varying the time span and the number of provinces considered. The outcome of this exercise is asymptotic equivalence between STATA and TSP, whereas LIMDEP shows a persistent bias up to about one thousand Monte Carlo replications.

The three econometric software packages are equivalent as regards both usability and numerical accuracy. TSP seems to be the fastest and the simplest to work with; LIMDEP displays immediately a more thorough range of statistical tests; STATA probably offers the greatest variety of estimation commands. The crucial factor in deciding which package to use thus appears to be the experience researchers have already gained. 


\title{
Appendix 1. Program listing
}

\section{TSP Code}

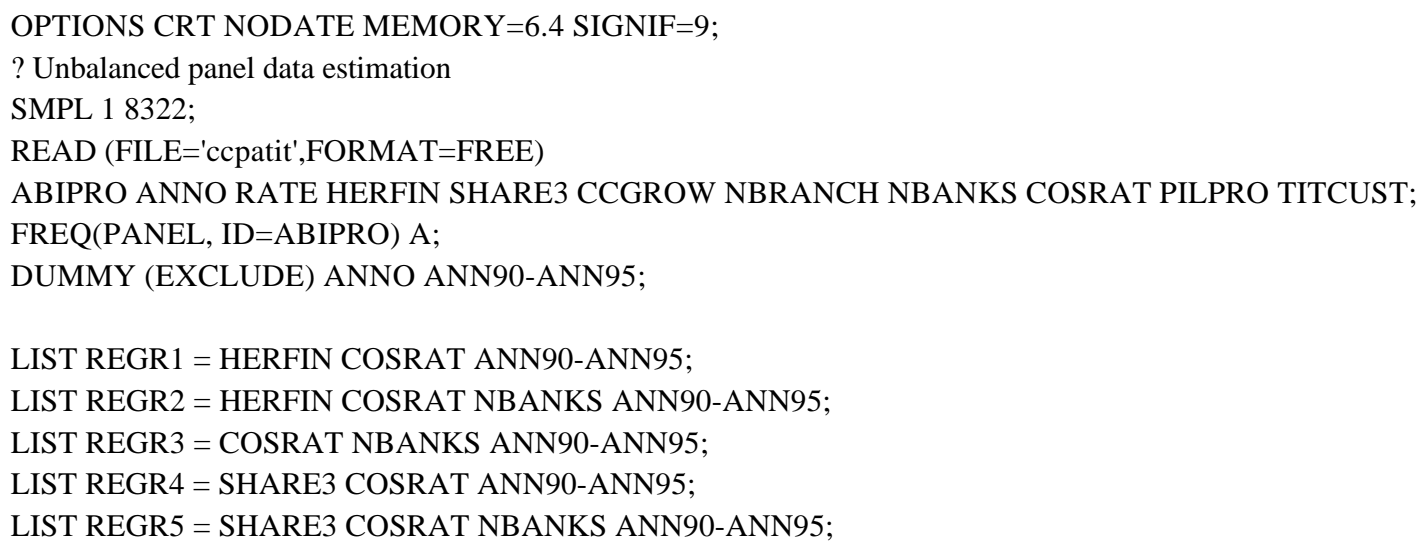

\section{LIMDEP Code}

\author{
? Limdep program for evaluating the determinants of the deposit rate \\ ? on the checking account \\ read; nobs $=8322$; nvar $=11$; \\ names $=$ abipro, anno, rate, herfin, share 3 , ccgrow, nbranch, nbanks, \\ cosrat, pilpro, titcust);file=/_saee/brunogi/RICGIUS/dati071999/ccpatit; \\ sample $=$ All $\$$ \\ sample; $1-7165,7243-8322 \$$ \\ ? create the yearly dummy variables. \\ create $; \mathrm{ann} 90=\mathrm{anno}=1990 ; \mathrm{ann} 91=\mathrm{anno}=1991 ; \mathrm{ann} 92=\mathrm{anno}=1992 ; \mathrm{ann} 93=\mathrm{anno}=1993$; \\ ann94=anno=1994;ann95=anno=1995 \$ \\ create $;$ tp $=$ anno $-1990 \$$ \\ namelist; regr1=herfin, cosrat, ann90,ann91, ann92,ann93,ann94,ann95\$ \\ namelist; regr2=herfin, cosrat,nbanks, ann90,ann91,ann92,ann93,ann94,ann95\$ \\ namelist; regr3 =cosrat,nbanks, ann90,ann91,ann92, ann93, ann94,ann95\$ \\ namelist; regr4=share3, cosrat, ann90,ann91,ann92,ann93,ann94,ann95\$ \\ namelist; regr5=share3, cosrat,nbanks, ann90,ann91,ann92,ann93,ann94,ann95\$ \\ regress $;$ lhs=rate; rhs=regr $3 ;$ str=abipro; perido $=$ tp; panel $\$$
}

\section{STATA Code}

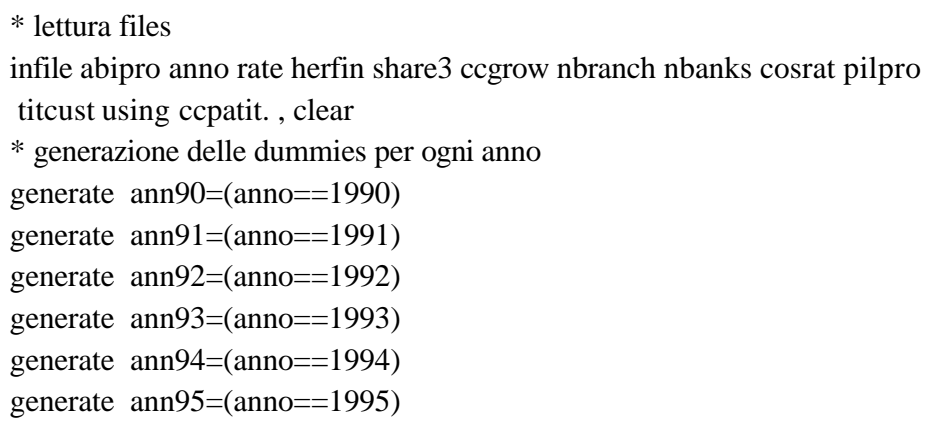


local regr1 "herfin cosrat ann90 ann91 ann92 ann93 ann94 ann95"

local regr2 "herfin cosrat nbanks ann90 ann91 ann92 ann93 ann94 ann95"

local regr3 "cosrat nbanks ann90 ann91 ann92 ann93 ann94 ann95"

local regr4 "share3 cosrat ann90 ann91 ann92 ann93 ann94 ann95"

local regr5 "share3 cosrat nbanks ann90 ann91 ann92 ann93 ann94 ann95"

xtreg rate `regr3', fe i(abipro)

xtreg rate `regr3', re i(abipro) th

xttest0

xthaus

The above program listings show only the first of the 5 estimation commands. The following tables also show the output containing the results of the first estimation:

\section{TSP Version 4.4 OUTPUT}

\section{EXECUTION}

Current sample: 1 to 7165,7243 to 8322

\section{PANEL DATA ESTIMATION}

Unbalanced data: $\mathrm{NI}=1307, \mathrm{TMIN}=1 \mathrm{TMAX}=7, \mathrm{NOB}=8245$

WITHIN (fixed effects) Estimates:

Dependent variable: RATE

Mean of dep. var. $=6.008486356$

Std. dev. of dep. var. $=1.394531738$

Sum of squared residuals $=2361.804409$

Variance of residuals $=.3408087170$

Std. error of regression $=.5837882467$

R-squared $=.8526842637$

Adjusted R-squared $=.8247516696$

LM het. test $=21.98008642[.000]$

Durbin-Watson $=1.606400250[.000, .000]$

$$
\text { Estimated Standard }
$$

Variable Coefficient Error t-statistic P-value

\begin{tabular}{lcccccc} 
COSRAT & $\mathbf{1 2 . 0 9 5 8 7 1 0 4}$ & $\mathbf{2 . 2 0 7 1 1 1 0 1 4}$ & $\mathbf{5 . 4 8 0 4 0 8 9 8 8}$ & \multicolumn{2}{c}{$[.000$} \\
NBANKS & $\mathbf{. 7 6 9 2 6 2 1 6 7 7}$ & $\mathbf{2}-02$ & $\mathbf{. 3 9 9 7 8 6 0 0 7 6 E - 0 2}$ & $\mathbf{1 . 9 2 4 1 8 4 8 2 2}$ \\
ANN90 & $\mathbf{2 . 4 0 5 8 5 9 4 8 0}$ & $\mathbf{. 0 2 7 8 0 0 8 8 0 1}$ & $\mathbf{8 6 . 5 3 8 9 6 8 2 1}$ & {$[.000]$} \\
ANN91 & $\mathbf{2 . 3 4 9 7 5 5 0 3 8}$ & $\mathbf{. 0 2 7 3 8 9 5 1 2 1}$ & $\mathbf{8 5 . 7 9 0 3 2 1 0 1}$ & {$[.000]$} \\
ANN92 & $\mathbf{2 . 9 0 0 8 3 4 8 8 5}$ & $\mathbf{. 0 2 6 1 2 4 8 2 7 6}$ & $\mathbf{1 1 1 . 0 3 7 4 7 4 9}$ & {$[.000]$} \\
ANN93 & $\mathbf{. 9 3 7 6 9 8 9 6 1 1}$ & $\mathbf{. 0 2 7 0 3 5 7 7 4 3}$ & $\mathbf{3 4 . 6 8 3 6 3 6 2 5}$ & {$[.000]$}
\end{tabular}




$\begin{array}{llllll}\text { ANN94 } & .2078109186 & .0251020549 & \mathbf{8 . 2 7 8 6 4 1 7 0 8} & {[.000]} \\ \text { ANN95 } & \mathbf{1 . 0 6 1 0 3 1 8 5 9} & \mathbf{. 0 2 3 5 9 8 0 7 6 4} & \mathbf{4 4 . 9 6 2 6 4 1 8 2} & {[.000]}\end{array}$

Variance Components (random effects) Estimates:

VWITH (variance of Uit) $=.34081$

VBET (variance of $\mathrm{Ai}$ ) $=.42730$

(computed from small sample formula)

THETA $(0=$ WITHIN, $1=$ TOTAL $)=.10229$

(evaluated at TMAX $=7$ )

Dependent variable: RATE

Mean of dep. var. $=6.008486356$

Std. dev. of dep. var. $=1.394531738$

Sum of squared residuals $=6387.212931$

Variance of residuals $=.7755236682$

Std. error of regression $=.8806382164$

R-squared $=.6016887144$

Adjusted R-squared $=.6013018166$

LM het. test $=98.56427090[.000]$

Durbin-Watson $=.5944021688[.000, .000]$

Estimated Standard

Variable Coefficient Error t-statistic P-value

$\begin{array}{lllll}\text { COSRAT } & 19.31537278 & \mathbf{1 . 8 0 2 4 0 6 3 5 0} & \mathbf{1 0 . 7 1 6 4 3 6 2 7} & {[.000]}\end{array}$

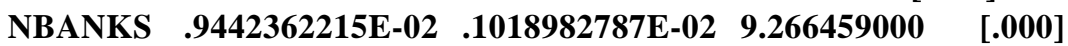

$\begin{array}{llllll}\text { ANN90 } & 2.357793776 & \mathbf{. 0 2 6 6 5 7 0 4 2 4} & \mathbf{8 8 . 4 4 9 1 8 8 9 5} & \text { [.000] }\end{array}$

$\begin{array}{llllll}\text { ANN91 } & \mathbf{2 . 2 9 7 3 9 5 1 2 0} & \mathbf{. 0 2 6 3 3 3 8 3 4 2} & \mathbf{8 7 . 2 4 1 1 9 3 2 0} & {[.000]}\end{array}$

$\begin{array}{llllll}\text { ANN92 } & \mathbf{2 . 8 5 4 9 0 1 0 4 0} & \mathbf{. 0 2 5 1 8 9 3 9 7 2} & \mathbf{1 1 3 . 3 3 7 4 0 9 9} & {[.000]}\end{array}$

$\begin{array}{llllll}\text { ANN93 } & \mathbf{. 8 8 5 4 8 9 9 5 4 2} & \mathbf{. 0 2 5 7 6 9 7 6 9 2} & \mathbf{3 4 . 3 6 1 5 7 8 8 3} & \text { [.000] }\end{array}$

$\begin{array}{llllll}\text { ANN94 } & \mathbf{. 1 7 2 0 9 9 5 5 1 3} & \mathbf{. 0 2 4 4 3 6 1 2 0 1} & \mathbf{7 . 0 4 2 8 3 4 5 7 2} & {[.000]}\end{array}$

$\begin{array}{llllll}\text { ANN95 } & 1.042947192 & \mathbf{. 0 2 3 4 8 0 0 7 8 2} & 44.41838659 & {[.000]}\end{array}$

$\begin{array}{llllll}C & 3.920533084 & \mathbf{. 0 5 5 8 8 2 1 0 8 1} & \mathbf{7 0 . 1 5 7 2 1 5 2 2} & {[.000]}\end{array}$

Hausman test of H0:RE vs. FE: $\operatorname{CHISQ}(8)=72.034, \mathrm{P}$-value $=[.0000]$

\section{Limdep Version 7.0 OUTPUT}

: LIMDEP Estimation Results

: Sample was reset SAMPLE 1-7165,7243-8322\$:

: Current sample contains 8245 observations.:

| OLS Without Group Dummy Variables

| Ordinary least squares regression Weighting variable $=$ ONE |

| Dependent variable is RATE Mean $=6.00849$, S.D. $=1.3945 \mid$

$\mid$ Model size: Observations $=$ 8245, Parameters $=$ 9, Deg.Fr. $=8236 \mid$

| Residuals: Sum of squares $=6326.1039$, Std.Dev. $=.87642 \mid$

| Fit: $\quad$ R-squared $=.60541$, Adjusted R-squared $=\quad .60503$ |

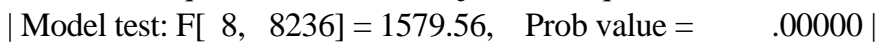


| Diagnostic: Log-L = -10607.0057, Restricted(b=0) Log-L = -14440.5947 |

| Amemiya Pr. Crt.= .769, Akaike Info. Crt.= 2.575 |

| Panel Data Analysis of RATE [ONE way]

Unconditional ANOVA (No regressors)

| Source Variation Deg. Free. Mean Square

| Between $\quad 4478.58 \quad 1306 . \quad 3.42923$

| Residual $\quad 11553.7 \quad 6938 . \quad 1.66528$

| Total $\quad 16032.3 \quad 8244 . \quad 1.94472$

Variable Coefficient Standard Error b/St.Er. P[|Z|>z] Mean of X

\begin{tabular}{|c|c|c|c|c|}
\hline COSRAT & 31.131 & 1.4090 & 22.095 & .00000 .2759E-0 \\
\hline NBANKS & $.90128 \mathrm{E}-0$ & $.51991 \mathrm{~F}$ & -03 17.3 & .0000025 \\
\hline ANN90 & 2.2087 & $.37649 E-01$ & 58.665 & 1216 \\
\hline ANN91 & 2.1643 & .37082E-01 & 58.365 & $\begin{array}{ll}.00000 & .1300\end{array}$ \\
\hline ANN92 & 2.7416 & .35932E-01 & 76.301 & $\begin{array}{ll}.00000 & .1460\end{array}$ \\
\hline ANN93 & .76425 & $.36114 \mathrm{E}-01$ & 21.162 & $\begin{array}{ll}.00000 & .1474\end{array}$ \\
\hline ANN94 & $.80676 \mathrm{E}-01$ & $.35486 \mathrm{E}-$ & 2.273 & .1500 \\
\hline NN95 & .97733 & $.34982 E-01$ & 27.938 & $\begin{array}{ll}.00000 & .1544\end{array}$ \\
\hline onstant & 3.6932 & $.44046 \mathrm{E}-01$ & 83.848 & .00000 \\
\hline
\end{tabular}

: LIMDEP Estimation Results :

: Current sample contains 8245 observations.:

| Least Squares with Group Dummy Variables

| Ordinary least squares regression Weighting variable $=$ ONE |

| Dependent variable is RATE Mean $=6.00849$, S.D. $=1.3945$ |

$\mid$ Model size: Observations $=$ 8245, Parameters $=* * *$, Deg.Fr. $=6930 \mid$

$\mid$ Residuals: Sum of squares $=2361.8043$, Std.Dev. $=.58379 \mid$

|Fit: $\quad$ R-squared $=.85268$, Adjusted R-squared $=\quad .82475 \mid$

$\mid$ Model test: $F[* * *, 6930]=30.53$, Prob value $=.00000 \mid$

| Diagnostic: Log-L = -6545.2768, Restricted(b=0) Log-L = -14440.5947|

| Amemiya Pr. Crt. = .395, Akaike Info. Crt. $=1.907 \mid$

| Estd. Autocorrelation of e(i,t) $\quad .002549$

|Estd. Autocorrelation of e(i,t) $\quad .002549$

Variable Coefficient Standard Error b/St.Er. P[|Z|>z] Mean of X

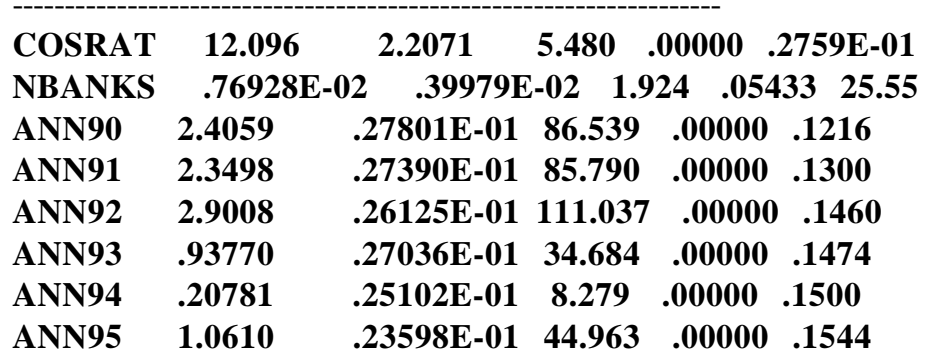

Test Statistics for the Classical Model
Model Log-Likelihood Sum of Squares R-squared |


| (1) Constant term only $-14440.59456 \quad .160323 \mathrm{D}+05 \quad .0000000$ |

| (2) Group effects only $-13090.06861 \quad .115537 \mathrm{D}+05 \quad .2793479$ |

| (3) X - variables only $-10607.00559 \quad .632610 \mathrm{D}+04 \quad 6054141$ |

| (4) $\mathrm{X}$ and group effects $-6545.27672 \quad .236180 \mathrm{D}+04 \quad .8526843$ |

Hypothesis Tests

Likelihood Ratio Test

F Tests

Chi-squared d.f. Prob. F num. denom. Prob value |

| (2) vs (1) $2701.052 \quad 1306 \quad .00000 \quad 2.0591306 \quad 6937 \quad .00000$ |

| (3) vs (1) $7667.178 \quad 8 \quad .00000 \quad 1579.565 \quad 8 \quad 8236 \quad .00000 \mid$

| (4) vs (1) $15790.636 \quad 1314 \quad .00000 \quad 30.5261314 \quad 6930 \quad .00000$ |

| (4) vs (2) $13089.584 \quad 8 \quad .00000 \quad 3371.348 \quad 8 \quad 6930 \quad .00000$ |

| (4) vs (3) $8123.458 \quad 1306 \quad .00000 \quad 8.9071306 \quad 6930 \quad .00000$ |

: LIMDEP Estimation Results

: Current sample contains 8245 observations.:

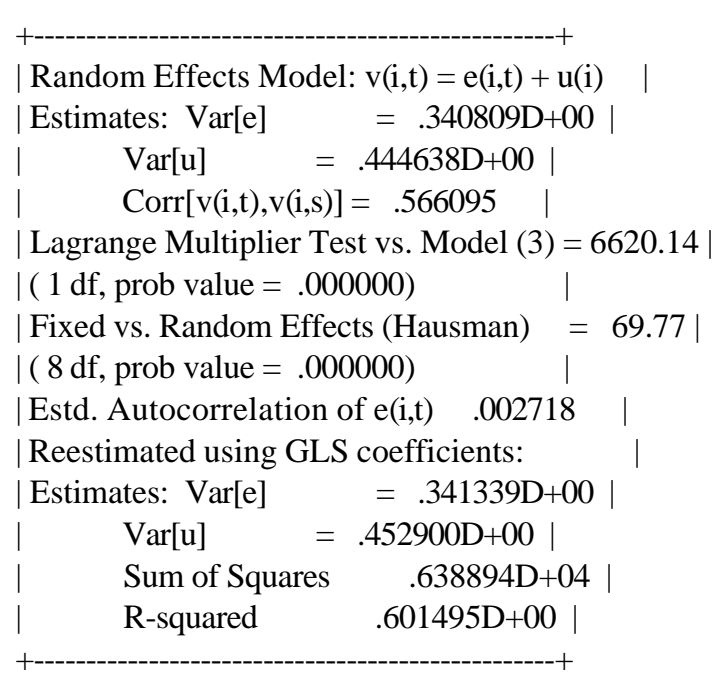

Variable Coefficient Standard Error b/St.Er. P[|Z|>z] Mean of X

\begin{tabular}{llllllll}
\hline COSRAT & 19.139 & 1.8129 & 10.557 & .00000 & $.2759 E-01$ \\
NBANKS & \multicolumn{2}{c}{$.94458 E-02$} & $.10359 E-02$ & 9.119 & .00000 & 25.55 \\
ANN90 & 2.3591 & $.26680 E-01$ & 88.423 & .00000 & .1216 \\
ANN91 & 2.2987 & $.26358 E-01$ & 87.213 & .00000 & .1300 \\
ANN92 & 2.8561 & $.25209 E-01$ & 113.296 & .00000 & .1460 \\
ANN93 & .88679 & $.25796 E-01$ & 34.377 & .00000 & .1474 \\
ANN94 & .17299 & $.24449 E-01$ & 7.076 & .00000 & .1500 \\
ANN95 & 1.0434 & $.23483 E-01$ & 44.434 & .00000 & .1544 \\
Constant & $\mathbf{3 . 9 2 4 5}$ & $.56392 E-01$ & 69.594 & .00000 &
\end{tabular}

STATA 6.0 OUTPUT

$\begin{array}{lrl}\text { Fixed-effects (within) regression } & \text { Number of obs }=8245 \\ \text { Group variable (i) : abipro } & \text { Number of groups }= & 1307\end{array}$

R-sq: within $=0.7956 \quad$ Obs per group: $\min =\quad 1$ 


$\begin{array}{lrl}\text { between }=0.1493 & \text { avg }= & 6.3 \\ \text { overall }=0.5956 & \max = & 7\end{array}$

$$
\begin{gathered}
\mathrm{F}(8,6930) \quad=3371.35 \\
\operatorname{corr}\left(\mathrm{u} \_\mathrm{i}, \mathrm{Xb}\right)=-0.0159 \text { Prob }>\mathrm{F}=0.0000
\end{gathered}
$$

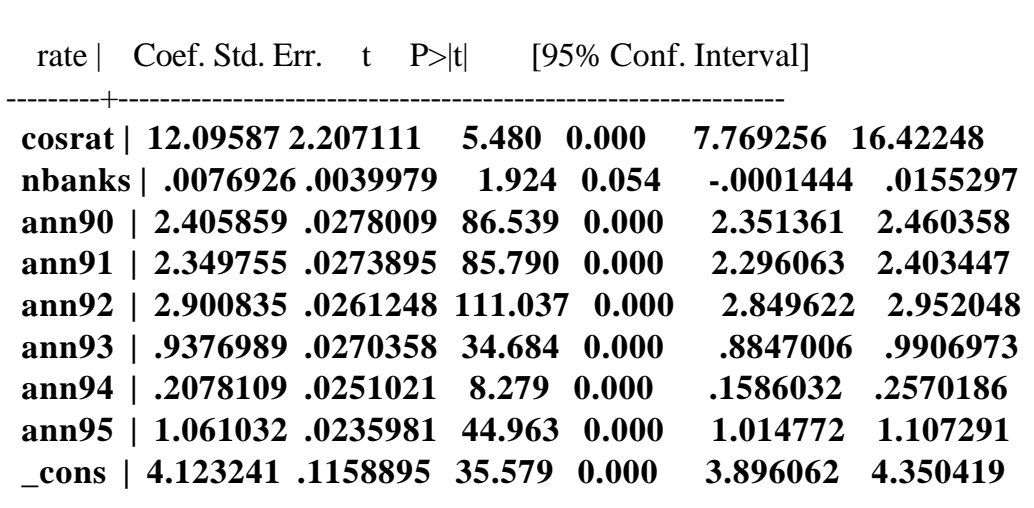

sigma_u .72386072

sigma_e | .58378825

rho .60590264 (fraction of variance due to u_i)

$F$ test that all $u \_i=0: F(1306,6930)=8.91$ Prob $>F=0.0000$

.xtreg rate 'regr3', re i(abipro) th

Random-effects GLS regression Number of obs $=8245$

Group variable (i) : abipro Number of groups $=1307$

R-sq: within $=0.7953$ Obs per group: $\min =1$

$$
\begin{array}{lc}
\text { between }=0.1679 & \text { avg }=6.3 \\
\text { overall }=0.6017 & \max =7
\end{array}
$$

Random effects u_i $\sim$ Gaussian $\quad$ Wald chi2(8) $=27010.51$

\begin{tabular}{|c|c|c|c|c|c|c|}
\hline & & 1.81 & 10.649 & 0.000 & 15 & \\
\hline & & & 9.206 & & & \\
\hline & & .02 & 88. & & & \\
\hline & 86 & .02 & 86.965 & 0. & & \\
\hline & 2.8 & .02 & 112.978 & 00 & & 683 \\
\hline & .88 & .02 & 34.259 & 0.000 & & \\
\hline & .17 & .02 & 7.028 & 0.000 & .1 & .2 \\
\hline & & .02 & 44.285 & & 03 & 218 \\
\hline & & .05 & 69.819 & 0.000 & 1311 & 4.031473 \\
\hline
\end{tabular}

$\operatorname{corr}\left(\mathrm{u} \_\mathrm{i}, \mathrm{X}\right)=0$ (assumed) Prob $>$ chi2 $=0.0000$

$\begin{array}{clccc}\min & 5 \% & \text { median } & 95 \% & \max \\ 0.3355 & 0.4677 & 0.6814 & 0.6814 & 0.6814\end{array}$

rate $\mid$ Coef. Std. Err. $\quad \mathrm{z} \quad \mathrm{P}>|\mathrm{z}| \quad$ [95\% Conf. Interval] 


sigma_u | $\mathbf{. 6 5 6 4 7 6 7 9}$
sigma_e $\mathbf{. 5 8 3 7 8 8 2 5}$
rho $\mid \mathbf{. 5 5 8 4 0 6 6 5}$ (fraction of variance due to u_i)

xttest0

Breusch and Pagan Lagrangian multiplier test for random effects:

rate[abipro,t $]=\mathrm{Xb}+\mathrm{u}[$ abipro $]+\mathrm{e}[$ abipro,t $]$

Estimated results:

\begin{tabular}{|c|c|c|}
\hline & Var & $=\operatorname{sqrt}(\operatorname{Var})$ \\
\hline rate | & 1.944719 & 1.394532 \\
\hline $\mathrm{e} \mid$ & .3408087 & .58378825 \\
\hline $\mathrm{u} \mid$ & .4309618 & .65647679 \\
\hline
\end{tabular}

Test: $\operatorname{Var}(\mathrm{u})=0$

$$
\begin{gathered}
\operatorname{chi} 2(1)=6620.14 \\
\text { Prob }>\text { chi } 2=0.0000
\end{gathered}
$$

.xthaus

Hausman specification test

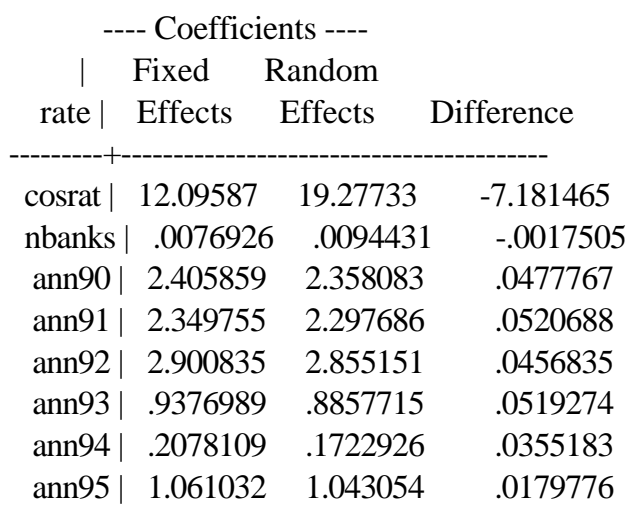

Test: Ho: difference in coefficients not systematic

$\operatorname{chi} 2(8)=(b-B)^{\prime}\left[S^{\wedge}(-1)\right](b-B), S=($ S_fe - S_re $)=80.62$

Prob $>$ chi $2=0.0000$ 


\section{Appendix 2. The data}

The data refer to the larger part of those banks which belong to the sample producing quarterly information for the Central Credit Register on deposit interest rates. Tha data set have been arranged considering the individual code of each bank and the province where it is active. Outliers have been corrected or erased.

The data set on total deposit interest rates refers to the years 1990-99 and contains 10561 observations. The data set on current accounts contains, for the period 1990-96, 8237 observations. The data set on certificates of deposit includes, for the period 1990-96, 8.017 observations. The data set on savings accounts includes 8248 observations.

The dependent variables are the different interest rates for the categories of deposits. Independent variables include the provincial Herfindahl indices and the concentration ratios R3 for the different categories of deposits; these indicators have been built considering all the Italian banks except for the mutual banks. The data set also consider the number of banks and branches per province; the costs/assets ratio and the staff costs per employee for each bank; the growth rate of deposits in each province. 


\section{Bank interest rates}

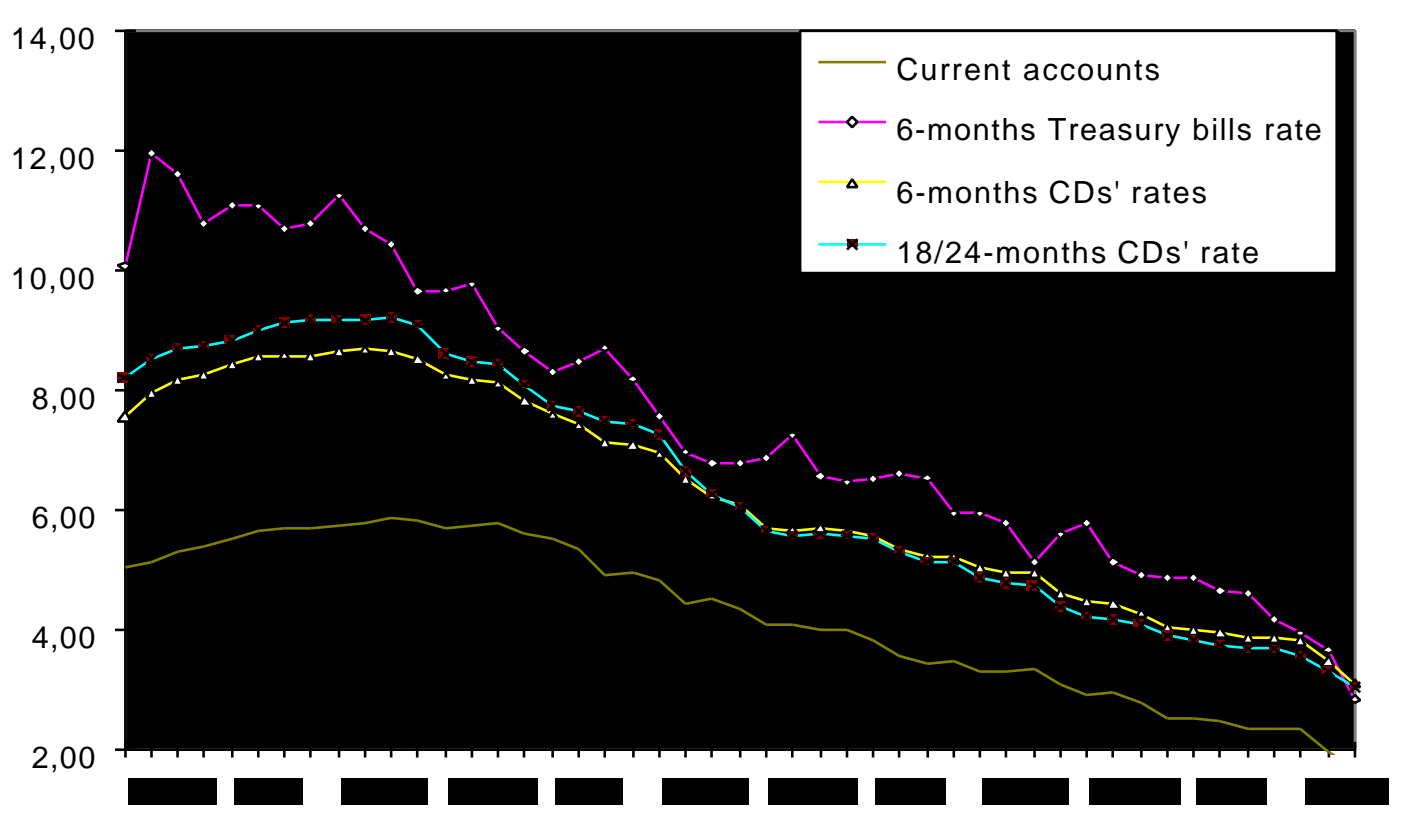


Table 1

Banks deposits

(percentages; end of period data)

\begin{tabular}{|c|c|c|c|c|c|c|}
\hline \multirow{4}{*}{ Year } & \multicolumn{6}{|c|}{ Deposits in lire } \\
\hline & \multirow{3}{*}{$\begin{array}{l}\text { Current } \\
\text { Accounts }\end{array}$} & \multirow{3}{*}{$\begin{array}{l}\text { Savings } \\
\text { Deposits }\end{array}$} & \multicolumn{3}{|c|}{ Certificates of deposit } & \multirow[t]{3}{*}{ Total } \\
\hline & & & \multicolumn{3}{|c|}{ of which: } & \\
\hline & & & & Short-term & long-term & \\
\hline 1974 & 55.23 & 40.98 & 3.79 & 0.00 & 3.79 & 100.00 \\
\hline 1975 & 48.93 & 47.14 & 3.93 & 0.00 & 3.93 & 100.00 \\
\hline 1976 & 48.79 & 47.82 & 3.39 & 0.00 & 3.39 & 100.00 \\
\hline 1977 & 48.89 & 47.76 & 3.35 & 0.00 & 3.35 & 100.00 \\
\hline 1978 & 50.55 & 46.05 & 3.40 & 0.00 & 3.40 & 100.00 \\
\hline 1979 & 52.40 & 44.67 & 2.93 & 0.00 & 2.93 & 100.00 \\
\hline 1980 & 53.24 & 43.89 & 2.88 & 0.00 & 2.88 & 100.00 \\
\hline 1981 & 52.38 & 44.26 & 3.35 & 0.00 & 3.35 & 100.00 \\
\hline 1982 & 51.21 & 43.52 & 5.26 & 0.00 & 5.26 & 100.00 \\
\hline 1983 & 51.01 & 43.44 & 5.55 & 0.84 & 4.71 & 100.00 \\
\hline 1984 & 51.20 & 42.00 & 6.80 & 1.73 & 5.06 & 100.00 \\
\hline 1985 & 51.16 & 41.02 & 7.82 & 2.73 & 5.09 & 100.00 \\
\hline 1986 & 52.89 & 37.83 & 9.28 & 4.07 & 5.20 & 100.00 \\
\hline 1987 & 53.35 & 35.67 & 10.98 & 5.63 & 5.35 & 100.00 \\
\hline 1988 & 52.85 & 31.14 & 16.01 & 7.25 & 8.76 & 100.00 \\
\hline 1989 & 52.90 & 26.85 & 20.25 & 8.50 & 11.75 & 100.00 \\
\hline 1990 & 52.02 & 23.71 & 24.27 & 9.95 & 14.32 & 100.00 \\
\hline 1991 & 53.09 & 19.66 & 27.25 & 9.89 & 17.36 & 100.00 \\
\hline 1992 & 50.66 & 16.97 & 32.36 & 10.83 & 21.53 & 100.00 \\
\hline 1993 & 50.28 & 15.42 & 34.29 & 9.50 & 24.80 & 100.00 \\
\hline 1994 & 51.79 & 14.71 & 33.51 & 7.77 & 25.73 & 100.00 \\
\hline 1995 & 51.05 & 12.66 & 36.29 & 6.30 & 29.99 & 100.00 \\
\hline 1996 & 52.80 & 11.97 & 35.23 & 6.98 & 28.25 & 100.00 \\
\hline 1997 & 61.66 & 13.12 & 25.22 & 9.77 & 15.45 & 100.00 \\
\hline 1998 & 69.97 & 12.98 & 17.06 & 8.41 & 8.65 & 100.00 \\
\hline 1999 & 75.83 & 12.49 & 11.67 & 6.39 & 5.28 & 100.00 \\
\hline
\end{tabular}


Summary Statistics (1990-96)

Current account rate

Average

6.01

9.19

5.95

7.02

0.18

62.0

264

25

2.75

51797

25.7 mil.

Per capita provincial income (in

lire)

$\begin{array}{cc}\text { Minimum } & \text { Maximum } \\ 1.98 & 10.79 \\ 1.12 & 14.50 \\ 1.00 & 11.27 \\ 2.72 & 10.97 \\ 0.06 & 0.46 \\ 33.0 & 96.0 \\ 11 & 1834 \\ 4 & 115 \\ 0.58 & 5.12 \\ 34119 & 82894 \\ & \\ 11 \mathrm{mil} . & 43 \mathrm{mil} .\end{array}$

(1990-99)

$R 3$

Branches per province

Banks per province

Herfindahl index

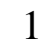

R3

0.83
-0.30
-0.37
-0.04
0.01

1

Branches per provinces

$-0.33$

$-0.38$

1

Banks per province

$-0.01$

0.66

1

Costs/total assets

$-0.01$

$-0.08$

$-0.02$

Staff costs per employee

\section{Costs/total assets Staff costs per}

employee

Costs/total assets

1

Staff costs per employee

$$
-0.15
$$

1

Summary Statistics for the Five Italian Macroregions: 1990-1999

(number of observations and average values of the variables)

\begin{abstract}
Number of observations
Deposits' interest rate (\%)

Herfindahl index

Concentration ratio

Banks per province
\end{abstract}

$\begin{array}{cccccc}\text { NorthWest } & \text { NorthEast } & \text { Center } & \text { South } & \text { Islands } & \text { Italy } \\ 2980 & 2899 & 2117 & 1689 & 876 & 10561 \\ 5.92 & 5.88 & 5.74 & 5.52 & 5.45 & 5.77 \\ 0.17 & 0.22 & 0.21 & 0.18 & 0.24 & 0.20 \\ 59.7 & 68.1 & 67.1 & 60.2 & 67.3 & 64.2 \\ 27.3 & 27.4 & 25.7 & 16.4 & 14.1 & 24.3\end{array}$


Costs/assets (\%)

Staff costs per employee (euro)
2.75

53425
2.69

53596
2.72

54030
2.67

54322
2.66

54511
2.71

53827 
Table 3

\section{DETERMINANTS OF DEPOSIT INTEREST RATES PANEL ESTIMATION, 1990-99}

Dependent variable: banks' deposit rate in each province.

Independent variables: Herfindahl index for deposits' market shares (HER); concentration ratio (R3), i.e. sum of the first 3 banks' market shares per province; staff costs per employee (COSPER); costs/total assets (COSRAT); number of banks per province (NBANKS). Variables refer to end-of-year data, for the period 1990-99. Regressions include time dummy variables, whose coefficients are not reported. $\mathrm{t}-$ statistics in brackets. * Significant at 1 per cent. ** Significant at 5 per cent. *** Significant at 10 per cent.

(i)

Fixed

effects

$-0.22$

$(-0.79)$

R3

\section{NBANKS}

COSPER

COSRAT (ii)

Fixed

effects (iii)

Fixed

effects (iv)

Fixed

effects (v)

Fixed

effects
$-0.25$

$(-0.88)$

$-0.33 \quad * * *$

$(-1.92)$

0.0028

(3.91)

$-6.35$

$(-4.41)$

3.94

(2.29)
(2.35)
(3.93)

$-6.36$

$(-4.41)$

3.91

(2.27)
$-0.36 \quad * *$

$(-2.05)$

$0.0029 *$

(3.97)

$-6.34$

$(-4.40)$

$3.92 * *$

(2.28)

$\begin{array}{lccccc}\begin{array}{l}\text { Number of } \\ \text { observations }\end{array} & 10561 & 10561 & 10561 & 10561 & 10561 \\ \mathrm{R}^{2} & 0.95 & 0.95 & 0.95 & 0.95 & 0.95 \\ \begin{array}{l}\text { Sum squared } \\ \text { residuals }\end{array} & 2839.1 & 2838.22 & 2834.67 & 2834.43 & 2833.38 \\ \begin{array}{l}\text { Hausman test } \\ \text { 136.87 }\end{array} & 139.47 & 137.86 & 139.33 & 143.65\end{array}$




\section{DETERMINANTS OF DEPOSIT INTEREST RATES PANEL ESTIMATION, 1990-99}

Dependent variable: banks' deposit rate in each province.

Independent variables: Herfindahl index for deposits' market shares (HER); staff costs per employee (COSPER); costs/total assets (COSRAT). Variables refer to end-of-year data, for the period 1990-99. Regressions include time dummy variables, whose coefficients are not reported. $\mathrm{t}$ - statistics in brackets. * Significant at 1 per cent. ** Significant at 5 per cent. *** Significant at 10 per cent.

(i)

Fixed

effects

HER

COSPER

COSRAT

$-0.23$

$(-0.83)$

(-3.9) (ii)

Fixed

Effects

$-0.22$

$(-0.78)$

$-5.0 *$

0.75

(0.48)

$\begin{array}{lcc}\text { N. observations } & 10561 & 10561 \\ \mathrm{R}^{2} & 0.95 & 0.95 \\ \text { Sum of squared } & 2840.9 & 2845.4 \\ \text { residuals } & & \\ \text { Hausman test } & 100.9 & 131\end{array}$


Table 5

\section{DETERMINANTS OF DEPOSIT INTEREST RATES \\ CROSS-SECTIONS (OLS), 1990-99}

Dependent variable : banks' deposit rate in each province.

Independent variables: Herfindahl index for deposit market shares (HER); staff costs per employee (COSPER); costs/total assets (COSRAT); number of banks per province (NBANKS). Variables refer to end-of-year data, for the period 1990-95. $\mathrm{t}$ - statistics in brackets. * Significant at 1 per cent. ** Significant at 5 per cent. *** Significant at 10 per cent.

$\begin{array}{cccccc}\text { (i) } & \text { (ii) } & \text { (iii) } & \text { (iv) } & \text { (v) } & \text { (vi) } \\ 1990 & 1991 & 1992 & 1993 & 1994 & 1995\end{array}$

$\begin{array}{lccccccccccccc}\text { HER } & 0.14 & & 0.23 & & -0.21 & & 0.35 & & -0.07 & & -0.11 & \\ & (0.54) & & (0.98) & & (-0.6) & & (1.44) & & (-0.31) & & (-0.43) \\ \text { COSPER } & 23.31 & * & 25.77 & * & 43.92 & * & -4.79 & * * * & -20.35 & * & -6.23 & \\ & (2.81) & & (3.82) & & (5.12) & & (-1.72) & & (-4.95) & & (-1.31) & \\ \text { COSRAT } & -28.75 & * & -10.75 & * & 1.68 & & 16.77 & * & -16.32 & * & 13.72 & * \\ & (-5.25) & & (-2.11) & & (0.27) & & (3.03) & & (-3.70) & & (2.74) & \\ \text { COSTANT } & 7.62 & * & 6.98 & * & 6.60 & * & 6.33 & * & 7.45 & * & 6.98 & * \\ & (29.44) & & (26.17) & & (15.69) & & (35.11) & & (34.11) & & (28.20) & \end{array}$

$\begin{array}{lrccccr}\text { N. observat. } & 804 & 928 & 1088 & 1115 & 1150 & 1177 \\ \mathrm{R}^{2} & 0,03 & 0,02 & 0,02 & 0,01 & 0,05 & 0,01 \\ \text { Sum squared } & 404 & 388 & 1260 & 646 & 576 & 740\end{array}$

residuals

$\begin{array}{rccccc}\text { (i) } & \text { (ii) } & \text { (iii) } & \text { (iv) } & \text { (v) } & \text { (vi) } \\ 1990 & 1991 & 1992 & 1993 & 1994 & 1995\end{array}$

$\begin{array}{lcccccccccccc}\text { HERF } & 0.42 & & 0.40 & & 0.16 & & 0.33 & & -0.04 & & 0.36 & \\ & (1.49) & & (1.62) & & (0.44) & & (1.28) & & (-1.17) & & (1.25) & \\ \text { NBANKS } & 0.01 & * & 0.01 & * * & 0.01 & * & -0.01 & & 0.01 & & 0.01 & * \\ & (2.69) & & (2.02) & & (3.63) & & (-0.3) & & (0.37) & & (3.68) & \\ \text { COSPER } & 21.46 & * * & 24.66 & * & 43.13 & * & -4.80 & * * & -20.33 & * & -5.60 & \\ & & & & & & & & * & & & & \\ & (2.59) & & (3.65) & & (5.05) & & (-1.72) & & (-4.94) & & (-1.18) & \\ \text { COSRAT } & -27.79 & * & -10.14 & * * & 1.26 & & 16.70 & * & -16.27 & * & 13.13 & * \\ & (-5.08) & & (-1.99) & & (0.20) & & (3.01) & & (-3.69) & & (2.63) & \\ \text { COSTANT } & 7.47 & * & 6.88 & * & 6.35 & * & 6.35 & * & 7.43 & * & 6.72 & * \\ & (28.37) & & (25.48) & & (14.97) & & (32.94) & & (32.56) & & (26.25) & \\ & & & & & & & & & & & & \\ \text { N. observat. } & 804 & & 928 & & 1088 & & 1115 & & 1150 & & 1177 & \\ \mathrm{R}^{2} & 0.04 & & 0.02 & & 0.03 & & 0.01 & & 0.05 & & 0.01 & \\ \text { Sum square } & 400 & & 386 & & 1245 & & 646 & & 576 & & 732 & \end{array}$


Table 5 (follows)

\section{DETERMINANTS OF DEPOSIT INTEREST RATES \\ CROSS-SECTIONS (OLS), 1990-99}

Dependent variable : banks' deposit rate in each province.

Independent variables: Herfindahl index for deposit market shares (HER); staff costs per employee (COSPER); costs/total assets (COSRAT); number of banks per province (NBANKS). Variables refer to end-of-year data, for the period 1996-99. $\mathrm{t}$ - statistics in brackets. * Significant at 1 per cent. $* *$ Significant at 5 per cent. $* * *$ Significant at 10 per cent.

$\begin{array}{cccc}\text { (i) } & \text { (ii) } & \text { (iii) } & \text { (iv) } \\ 1996 & 1997 & 1998 & 1999\end{array}$

$\begin{array}{lcccccccc}\text { HER } & 0.22 & & 0.25 & & 0.39 & * * & 0.46 & * \\ & (1.11) & & (1.22) & & (2.26) & & (3.08) & \\ \text { COSPER } & -37.44 & * & -12.89 & * & -25.80 & * & -15.42 & * \\ & (-10.39) & & (-3.29) & & (-7.43) & & (-7.02) & \\ \text { COSRAT } & -47.66 & * & -33.72 & * & -38.24 & * & -1.76 & \\ & (-8.71) & & (-7.86) & & (-11.09) & & (-0.72) & \\ \text { COSTANT } & 9.25 & * & 5.97 & * & 4.76 & * & 2.38 & * \\ & (33.92) & & (22.62) & & (20.36) & & (16.69) & \end{array}$

$\begin{array}{lcccc}\text { N. observat. } & 1175 & 1022 & 1056 & 1046 \\ \mathrm{R}^{2} & 0.12 & 0.06 & 0.12 & 0.05 \\ \text { Sum of } & 438 & 335 & 259 & 184\end{array}$

squared

residuals

$\begin{array}{cccc}\text { (i) } & \text { (ii) } & \text { (iii) } & \text { (iv) } \\ 1996 & 1997 & 1998 & 1999\end{array}$

$\begin{array}{lcccccccc}\text { HERF } & 0.21 & & 0.35 & & 0.61 & * & 0.47 & * \\ & (0.95) & & (1.59) & & (3.21) & & (2.83) & \\ \text { NBANKS } & -0.01 & & 0.01 & & 0.01 & * & 0.01 & \\ & (-0.15) & & (1.23) & & (2.79) & & (0.08) & \\ \text { COSPER } & -37.47 & * & -12.48 & * & -25.44 & * & -15.40 & * \\ & (-10.38) & & (-3.17) & & (-7.35) & & (-6.95) & \\ \text { COSRAT } & -47.65 & * & -33.75 & * & -38.64 & * & -1.77 & \\ & (-8.70) & & (-7.87) & & (-11.23) & & (-0.72) & \\ \text { COSTANT } & 9.26 & * & 5.88 & * & 4.63 & * & 2.38 & * \\ & (33.19) & & (21.60) & & (19.44) & & (15.66) & \end{array}$

$\begin{array}{lcccc}\text { N. observat. } & 1175 & 1022 & 1056 & 1046 \\ \mathrm{R}^{2} & 0.12 & 0.06 & 0.13 & 0.05 \\ \text { Sum squared } & 438 & 335 & 257 & 184\end{array}$

residuals 


\section{DETERMINANTS OF DEPOSIT INTEREST RATES: ITALIAN MACROREGIONS PANEL ESTIMATION, 1990-99}

Dependent variable: banks' deposit rate in each province.

Independent variables: Herfindahl index for deposit market shares (HER); concentration ratio (R3), i.e. sum of the first 3 banks' market shares per province; staff costs per employee (COSPER); costs/total assets (COSRAT). Variables refer to end-of-year data, for the period 1990-99. Regressions include time dummy variables, whose coefficients are not reported. $\mathrm{t}$ - statistics in brackets. * Significant at 1 per cent. ** Significant at 5 per cent. *** Significant at 10 per cent. Fixed-effects regressions, selected according to the Hausman test.

(i)

North-West (ii)

North-East (iii)

Center (iv)

South (v)

Islands

\begin{tabular}{|c|c|c|c|c|c|c|c|c|c|}
\hline HER & $\begin{array}{c}1.21 \\
(1.78)\end{array}$ & $* * *$ & $\begin{array}{c}0.51 \\
(0.97)\end{array}$ & & $\begin{array}{c}-1.35 \\
(-2.12)\end{array}$ & $* *$ & $\begin{array}{c}-0.19 \\
(-0.25)\end{array}$ & & $\begin{array}{c}-0.19 \\
(-0.20)\end{array}$ \\
\hline COSPER & $\begin{array}{c}0.74 \\
(0.28)\end{array}$ & & $\begin{array}{l}-7.55 \\
(-2.67)\end{array}$ & $*$ & $\begin{array}{c}-6.50 \\
(-2.09)\end{array}$ & $*$ & $\begin{array}{l}-18.29 \\
(-4.88)\end{array}$ & $*$ & $\begin{array}{l}-20.86 \\
(-3.80)\end{array}$ \\
\hline COSRAT & $\begin{array}{c}-2.38 \\
(-0.79)\end{array}$ & & $\begin{array}{c}1.66 \\
(0.49)\end{array}$ & & $\begin{array}{c}1.57 \\
(0.41)\end{array}$ & & $\begin{array}{l}14.57 \\
(2.97)\end{array}$ & $*$ & $\begin{array}{l}31.02 \\
(4.74)\end{array}$ \\
\hline N. observat. & 2980 & & 2899 & & 2117 & & 1689 & & 876 \\
\hline $\mathrm{R}^{2}$ & 0.95 & & 0.95 & & 0.94 & & 0.94 & & 0.94 \\
\hline $\begin{array}{l}\text { Sum squared } \\
\text { residuals }\end{array}$ & 693.57 & & 718.66 & & 611.79 & & 482.01 & & 246.68 \\
\hline Hausman test & 75.63 & & 92.69 & & 23.11 & & 25.53 & & 32.67 \\
\hline & (i) & & (ii) & & (iii) & & (iv) & & (v) \\
\hline & North-West & & North-East & & Center & & South & & Islands \\
\hline R3 & $\begin{array}{c}0.44 \\
(1.60)\end{array}$ & & $\begin{array}{c}-0.64 \\
(-1.77)\end{array}$ & $* * *$ & $\begin{array}{c}-0.93 \\
(-1.83)\end{array}$ & $* * *$ & $\begin{array}{l}-0.10 \\
(-0.22)\end{array}$ & & $\begin{array}{c}-1.42 \\
(-1.51)\end{array}$ \\
\hline COSPER & $\begin{array}{c}0.64 \\
(0.24)\end{array}$ & & $\begin{array}{c}-7.39 \\
(-2.61)\end{array}$ & $*$ & $\begin{array}{c}-6.61 \\
(-2.12)\end{array}$ & $* *$ & $\begin{array}{l}-18.29 \\
(-4.88)\end{array}$ & $*$ & $\begin{array}{l}-20.36 \\
(-3.72)\end{array}$ \\
\hline COSRAT & $\begin{array}{c}-2.51 \\
(-0.84)\end{array}$ & & $\begin{array}{c}1.63 \\
(0.48)\end{array}$ & & $\begin{array}{c}1.64 \\
(0.43)\end{array}$ & & $\begin{array}{l}14.54 \\
(2.97)\end{array}$ & $*$ & $\begin{array}{l}29.75 \\
(4.58)\end{array}$ \\
\hline N. observat. & 2980 & & 2899 & & 2117 & & 1689 & & 876 \\
\hline $\mathrm{R}^{2}$ & 0,95 & & 0,95 & & 0,94 & & 0,94 & & 0,94 \\
\hline $\begin{array}{l}\text { Sum squared } \\
\text { residuals }\end{array}$ & 693,74 & & 718,03 & & 612,16 & & 482,01 & & 245,94 \\
\hline Hausman test & 76,15 & & 97,96 & & 22,55 & & 25,80 & & 33,09 \\
\hline
\end{tabular}




\section{DETERMINANTS OF CURRENT ACCOUNTS INTEREST RATES PANEL ESTIMATION, 1990-96}

Dependent variable: current accounts' rates in each province.

Independent variables: Herfindahl index for current accounts' market shares (HER); concentration ratio (R3), i.e. sum of the first 3 banks' market shares per province; staff costs per employee (COSPER); costs/total assets (COSRAT); number of banks per province (NBANKS). Variables refer to end-of-year data, for the period 1990-96. Regressions include time dummy variables, whose coefficients are not reported. $\mathrm{t}-$ statistics in brackets. * Significant at 1 per cent. ** Significant at 5 per cent. *** Significant at 10 per cent.

(i)

Fixed

effects

$-0.87 * *$

$(-1.91)$

R3

NBANKS

\section{COSPER}

COSRAT

HER$$
\text { (-1.91 }
$$

(ii)

Fixed

effects

$-0.99$

$-3.65$

N. observat.

8237

0.85

Sum of squared 2342.05

residuals

Hausman test

47.30
8237

0.85

2338.77

53.81 (iii)

Fixed effects (iv)

Fixed

effects

$-0.77 \quad * * *$

$(-1.68)$

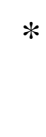

$*$

$\begin{array}{cc} & \\ 0.007 & * * \\ (1.98) & \\ -8.83 & * \\ (-4.28) & \\ 19.66 & * \\ (6.64) & \end{array}$

8237

0.85

2341.96

49.43
8237

0.85

2341.01

58.50
(1.75)

$(-4.25)$

19.58

(6.61) (v)

Fixed

effects

$-8.77 * \quad-8.66$

$(-4.20)$

$19.43 *$

(6.56)

8237

0.85

2338.00

76.70 
Table 8

\section{DETERMINANTS OF CERTICATES OF DEPOSIT INTEREST RATES PANEL ESTIMATION, 1990-96}

Dependent variable: rates on certificates of deposit in each province.

Independent variables: Herfindahl index for market shares of certificates of deposit (HER); concentration ratio (R3), i.e. sum of the first 3 banks' market shares per province; staff costs per employee (COSPER); costs/total assets (COSRAT); number of banks per province (NBANKS). Variables refer to end-of-year data, for the period 1990-96. Regressions include time dummy variables, whose coefficients are not reported. $\mathrm{t}$ - statistics in brackets. * Significant at 1 per cent. ** Significant at 5 per cent. *** Significant at 10 per cent.

(i)

Fixed

effects

$-0.45$

$(-1.22)$

R3

NBANKS

COSPER

COSRAT

HER (ii)

Fixed

effects

0.50

(1.22)
$12.93 *$

$-19.54$

(-3.29)

$*$

(iii)

Fixed

Effects (iv)

Fixed

effects

$-0.41$

$(-1.10)$ (v)

Fixed

effects

12.76

$(-3.25)$

0.009

(1.33)

12.80

(3.13)

$-19.35$

$(-3.25)$

0.009

(1.22)

12.84

(3.14)

$-19.41$

$(-3.26)$ $-19.18$ (-3.23)

$\begin{array}{lccccc}\text { N. observat. } & 8017 & 8017 & 8017 & 8017 & 8017 \\ \mathrm{R}^{2} & 0.71 & 0.71 & 0.71 & 0.71 & 0.71 \\ \text { Sum squared } & 7641.80 & 7641.81 & 7641.49 & 7640.10 & 7639.20 \\ \text { residuals } & & & & & \\ \text { Hausman test } & 66.63 & 66.73 & 65.69 & 68.05 & 67.49\end{array}$


Table 9

\section{DETERMINANTS OF CURRENT ACCOUNTS' INTEREST RATES \\ CROSS-SECTIONS (OLS), 1990-96}

Dependent variable : banks' rates on current accounts in each province.

Independent variables: Herfindahl index for current accounts' market shares (HER); staff costs per employee (COSPER); costs/total assets (COSRAT); number of banks per province (NBANKS). Variables refer to end-ofyear data, for the period 1990-96. $\mathrm{t}$ - statistics in brackets. * Significant at 1 per cent. ** Significant at 5 per cent. *** Significant at 10 per cent.

$\begin{array}{lcccccc}\text { (i) } & \text { (ii) } & \text { (iii) } & \text { (iv) } & \text { (v) } & \text { (vi) } & \text { (vii) } \\ 1990 & 1991 & 1992 & 1993 & 1994 & 1995 & 1996\end{array}$

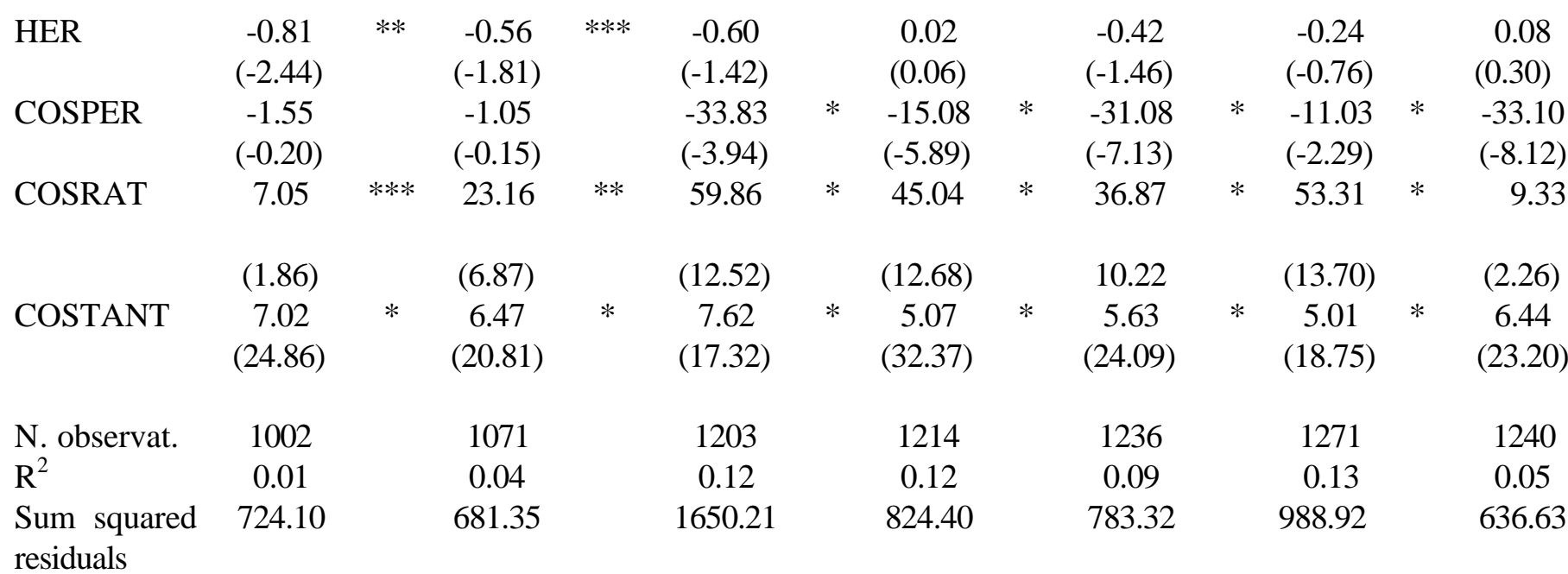
residuals

$\begin{array}{rcccccc}\text { (i) } & \text { (ii) } & \text { (iii) } & \text { (iv) } & \text { (v) } & \text { (vi) } & \text { (vii) } \\ 1990 & 1991 & 1992 & 1993 & 1994 & 1995 & 1996\end{array}$

\begin{tabular}{|c|c|c|c|c|c|c|c|c|c|c|c|c|c|}
\hline HERF & $\begin{array}{c}0.21 \\
(0.58)\end{array}$ & & $\begin{array}{c}0.33 \\
(0.97)\end{array}$ & & $\begin{array}{c}0.70 \\
(1.50)\end{array}$ & & $\begin{array}{c}0.86 \\
(2.62)\end{array}$ & $*$ & $\begin{array}{c}0.66 \\
(2.10)\end{array}$ & $* *$ & $\begin{array}{c}0.89 \\
(2.62)\end{array}$ & $*$ & $\begin{array}{c}1.00 \\
(3.48)\end{array}$ \\
\hline NBANKS & $\begin{array}{l}0.009 \\
(6.25)\end{array}$ & $*$ & $\begin{array}{l}0.007 \\
(5.59)\end{array}$ & $*$ & $\begin{array}{c}0.01 \\
(6.49)\end{array}$ & $*$ & $\begin{array}{l}0.008 \\
(5.76)\end{array}$ & $*$ & $\begin{array}{c}0.01 \\
(7.70)\end{array}$ & $*$ & $\begin{array}{c}0.01 \\
(7.60)\end{array}$ & $*$ & $\begin{array}{c}0.01 \\
(7.73)\end{array}$ \\
\hline COSPER & $\begin{array}{c}-3.55 \\
(-0.47)\end{array}$ & & $\begin{array}{l}-1.96 \\
(-0.29)\end{array}$ & & $\begin{array}{l}-33.06 \\
(-3.91)\end{array}$ & $*$ & $\begin{array}{l}-13.96 \\
(-5.50)\end{array}$ & $*$ & $\begin{array}{l}-29.02 \\
(-6.80)\end{array}$ & $*$ & $\begin{array}{l}-9.18 \\
(-1.95)\end{array}$ & $* * *$ & $\begin{array}{l}-31.19 \\
(-7.81)\end{array}$ \\
\hline COSRAT & 6.94 & $* * *$ & 22.51 & $*$ & 57.99 & $*$ & 44.53 & $*$ & 36.15 & $*$ & 51.54 & $*$ & 7.29 \\
\hline COSTANT & $\begin{array}{c}(1.86) \\
6.69 \\
(23.72)\end{array}$ & $*$ & $\begin{array}{c}(6.77) \\
6.16 \\
(19.81)\end{array}$ & $*$ & $\begin{array}{c}(12.31) \\
7.07 \\
(16.04)\end{array}$ & $*$ & $\begin{array}{c}(12.70) \\
4.66 \\
(27.47)\end{array}$ & $*$ & $\begin{array}{c}(10.25) \\
5.06 \\
(21.11)\end{array}$ & $*$ & $\begin{array}{c}(13.51) \\
4.43 \\
(16.32)\end{array}$ & $*$ & $\begin{array}{c}(1.80) \\
5.95 \\
(21.38)\end{array}$ \\
\hline $\begin{array}{l}\text { N. observat. } \\
\mathrm{R}^{2}\end{array}$ & $\begin{array}{l}1002 \\
0.04\end{array}$ & & $\begin{array}{l}1071 \\
0.07\end{array}$ & & $\begin{array}{l}1203 \\
0.15\end{array}$ & & $\begin{array}{l}1214 \\
0.14\end{array}$ & & $\begin{array}{l}1236 \\
0.13\end{array}$ & & $\begin{array}{l}1271 \\
0.17\end{array}$ & & $\begin{array}{l}1240 \\
0.09\end{array}$ \\
\hline $\begin{array}{l}\text { Sum squared } \\
\text { residuals }\end{array}$ & 696.75 & & 661.90 & & 1594.06 & & 802.36 & & 747.29 & & 945.70 & & 607.21 \\
\hline
\end{tabular}




\section{References}

Allen L., A. Saunders, G., F. Udell (1991), The Pricing of Retail Deposits: Concentration and Information, Journal of Financial Intermediation 1, pp. 335-361.

Angeloni, I., L. Buttiglione, G. Ferri ed E. Gaiotti (1995), The Credit Channel of Monetary Policy across Heterogeneous Banks: The Case of Italy, Banca d'Italia, Temi di discussione, n. 256.

Banca d'Italia (1996), La modifica del trattamento fiscale degli interessi sui depositi, Bollettino Economico, n. 27, ottobre 1996, pagg. 62-63.

Baltagi, B. H. (1995), Econometric Analysis of Panel Data, Chichester, Wiley.

Bellman L, Breitung J. And J. Wagner (1989), Bias Correction and Bootstrapping of Error Component Models for Panel data: Theory and Applications, Empirica Economics, vol. 14, pp. 329-342.

Berger, N. A. e T. H. Hannan (1989a), The Price-Concentration Relationship in Banking, in "Review of Economics and Statistics", vol. 71, n. 2, pp. 291-99.

Berger, N. A. e T. H. Hannan (1989b), Deposit Interest Rates and Local Market Concentration, in L. W. Weiss (a cura di), Concentration and Price, Cambridge MA, MIT Press, pp. 255-265. (1991), The Rigidity of Prices: Evidence from the Banking Industry, in "American Economic Review", vol. 81, n. 4, pp. 938-45.

(1992), The Price-Concentration Relationship in Banking: A Reply, in "Review of Economics and Statistics", vol. 74, n. 2, pp. 376-79.

Bianco M., F. Ghezzi, P. Magnani (2000), L'applicazione della disciplina antitrust nel settore bancario statunitense, in M. Polo (a cura di) 'Industria bancaria e concorrenza", Il Mulino, Bologna.

Biscaini, A. M., G. Carosio e T. Padoa-Schioppa (1972), Tassi attivi e passivi in un mercato oligopolistico, in Banca d'Italia, "Contributi alla ricerca economica", n. 2, pp. 41-76.

Blanchard P. (1992), Software Review, in "The Econometrics of Panel Data: handbook of theory and appplications”, pp. 521-546, Kluwer Academic Publishers, Dordrecht.

Cesarini F., V. Conti, M.L. Di Battista 1994,(a cura di), "Tendenze e prospettive della raccolta bancaria in Italia", Il Mulino, Bologna.

Conigliani C. e G. Lanciotti (1979), Struttura dell'offerta e tassi d'interesse nei mercati bancari italiani, in "Bancaria", n. 11, pp. 1123-36.

Corbisiero G. e N. Pesaresi (1999), Gli effetti delle concentrazioni bancarie sulle caratteristiche concorrenziali dei mercati dei depositi: evidenze empiriche e considerazioni teoriche, Banca d'Italia, 
mimeo.

D’Auria, C. e A. Foglia (1997), Le determinanti del tasso di interesse sui crediti alle imprese, Banca d'Italia, Temi di discussione, n. 293.

De Bonis R. e A. Ferrando (1997b), Da che cosa dipendono $i$ tassi di interesse sui prestiti nelle province?, Banca d'Italia, Temi di discussione, n. 319, settembre.

Di Battista M. L. (1996), Le politiche di raccolta delle banche, Il Mulino, Bologna.

Freixas e Rochet (1998), The Microeconomics of Banking, MIT Press, Cambridge, MA.

Gilbert, R. A. (1984), Bank, Market Structure and Competition, in "Journal of Money, Credit and Banking”, vol. 16, n. 4, pp. 617-45.

Hannan T. H. (1997), Market Share Inequality, the Number of Competitors, and the HHI: An Examination of Bank Pricing, Review of Industrial Organization, n. 12, pp. 23-35.

Jackson W. E. III (1992), The Price-Concentration Relationship, in "Review of Economics and Statistics", vol. 74, n. 2, pp. 373-76.

Maddala G. S. e T. D. Mount (1973), A Comparative Study of Alternative Estimators for Variance Components Models Used in Econometric Applications, in "Journal of American Statistical Association", vol. 68, Num. 342, pp. 324-328.

McCullogh B. D. e H. D. Vinod (1999), The Numerical Reliability of Econometric Software, in “Journal of Economic Literature”, vol. XXXVII, pp. 633-665.

Moore R. (1998), Concentration, Technology, and Markey Power in Banking: Is Distance Dead ? Financial Industry Studies, Federal Reserve Bank of Dallas, December, pp. 1-10.

Neuberger J. D. e G. Zimmerman (1990), Bank pricing of retail deposit accounts and the "California rate mistery”, Economic Review (Federal Reserve Bank of San Francisco), pp. 3-16.

Neumark D. e S. A. Sharpe (1992), Market Structure and the Nature of Price Rigidity: Evidence from the Market for Consumer Deposits, Quarterly Journal of Economics, vol. 107, n. 2, pp. 657-680.

Osborne D.K. (1992), Banking Structure and Competition, in The New Palgrave: Dictionary of Money and Finance.

Pittaluga G. B. (1994), La concorrenza nel mercato dei depositi bancari, in Cesarini , Conti, Di Battista (1994).

Prager R. A. e T. H. Hannan (1998), Do Substantial Horizontal Mergers Generate Significant Price Effects? Evidence from the Banking Industry, The Journal of Industrial Economics, volume XLVI, n. 4, dicembre.

Radecki L. J. (1998), The Expanding Geographic Reach of Retail Banking Markets, Federal Reserve 
Bank of New York, June, pp. 15-34.

Sharpe S. A. (1997), The Effect of Consumer Switching Costs on Prices: A Theory and its Application to the Bank Deposit Market, Review of Industrial Organization, n. 12, pp. 79-94.

Swami P.A. e S.S. Arora (1972), The exact finite sample properties of the estimators of coefficients in the error components regresion models, Econometrica, n. 40, pagg. 261-275.

Weiss, L. W. (1974), The Concentration-Profits Relationship and Antitrust, in H. J. Goldschmid e altri (a cura di), Industrial Concentration: The New Learning, Boston, Little Brown. (1989), A Review of Concentration-Price Studies in Banking, in L. W. Weiss (a cura di), Concentration and Price, Cambridge MA, MIT Press. 